\title{
Complicity and Lesser Evils: A Tale of Two Lawyers
}

David Luban

Georgetown University Law Center, luband@law.georgetown.edu

This paper can be downloaded free of charge from:

https://scholarship.law.georgetown.edu/facpub/2368

https://ssrn.com/abstract=3817495

Georgetown Journal of Legal Ethics, Vol. 34, Issue 3, Pp. 613.

This open-access article is brought to you by the Georgetown Law Library. Posted with permission of the author. Follow this and additional works at: https://scholarship.law.georgetown.edu/facpub

Part of the Law and Philosophy Commons, Legal Biography Commons, Legal Ethics and Professional Responsibility Commons, and the Legal History Commons 


\title{
Complicity and Lesser Evils: A Tale of Two Lawyers
}

\author{
DAVID LuBAN*
}

\begin{abstract}
Government lawyers and other public officials sometimes face an excruciating moral dilemma: to stay on the job or to quit, when the government is one they find morally abhorrent. Staying may make them complicit in evil policies; it also runs the danger of inuring them to wrongdoing, just as their presence on the job helps inure others. At the same time, staying may be their only opportunity to mitigate those policies - to make evils into lesser evils - and to uphold the rule of law when it is under assault. This Article explores that dilemma in a stark form: through the moral biographies of two lawyers in the Third Reich, both of whom stayed on the job, and both of whom can lay claim to mitigating evil. One, Helmuth James von Moltke, was an anti-Nazi, and a martyr of the resistance; the other, Bernhard Lösener, was a Nazi by conviction who nevertheless claimed to have secretly fought against the persecution of Jews from the improbable post of legal adviser on Jewish matters. The Article critically examines their careers and self-justifications. It frames its analysis through two philosophical arguments: Hannah Arendt's stern injunction that staying on the job is self-deception or worse, because like it or not, obedience is support; and a contemporary analysis of moral complicity by Chiara Lepora and Robert Goodin. The chief question, with resonance today as well as historically, is whether Arendt is right - and, if not, under what conditions lesser-evilism can succeed.
\end{abstract}

\section{TABle Of Contents}

INTRODUCTION

* University Professor in Law and Philosophy, Georgetown University Law Center; Distinguished Chair in Ethics, Stockdale Center for Ethical Leadership, United States Naval Academy. This paper would have been impossible without the help of my research assistants, Alistair Somerville and Gabrielle Metzger. Johannes Hegemann and Meredith Manuel-Ruley gave valuable editorial help, including with German-language sources. Thanks as well to Pierce Randall and Mitt Regan for comments on an early draft, and to Bob Goodin, Erica Newland, and Jim Whitman for their careful reading of a later draft and excellent suggestions. Finally, I am grateful to the Fellowships at Auschwitz for the Study of Professional Ethics, and especially to David Goldman, Eric Muller, and Thorsten Wagner. It was at FASPE's 2016 program that I first learned about the career of Bernhard Lösener. (C) 2021, David Luban. 
I. A Fable About Yesterday And TodAY . . . . . . . . . . 616

II. Hannah Arendt's Moral Argument . . . . . . . . . . . . . 619

III. LÖSENER AND MOLTKE: A DOUBle Moral BiograPhy. . 623

IV. A Note On SOURCES ...................... 625

V. LÖSENER At The Jewish Desk. . . . . . . . . . . . . . . . 627

VI. How LöSENer Got THERE . . . . . . . . . . . . . . . . . . . . . 629

VII. LÖSENER's BATTLES . . . . . . . . . . . . . . . . . . . . 636

VIII. StAYING Or QuitTING .................... 637

IX. SPIElRaum In The InTERIOR Ministry . . . . . . . . . . . 639

X. Von Moltke And The AbWehr. . . . . . . . . . . . . 640

XI. MoltKe's Legal Work . . . . . . . . . . . . . . . . . . . . 648

XII. MOLTKE's SPIELRAUM . . . . . . . . . . . . . . . . 650

XIII. MoltKe's CONSCIENCE. . . . . . . . . . . . . . . . . . . . . . . 652

XIV. TAKING STOCK. . . . . . . . . . . . . . . . . . . . 654

XV. BADNESS, RESPONSIBILITY, CONTRIBUTION, SHARED PURPOSE. . . . . . . . . . . . . . . . . . . . . . 657

XVI. Conditions For Lesser-Evilism To SucCEed . . . . . . . 660

XVII. AN EPILOGUE. . . . . . . . . . . . . . . . . . . . . . . . . 662 


\section{INTRODUCTION}

When a regime comes to power that does awful things, or tries to, or threatens to, how should decent people in the government respond? Staying in their jobs may turn them into "desk perpetrators"- a German label for officials who set wrongdoing in motion by drafting documents and signing papers in the quiet of an office. ${ }^{1}$ But quitting the job may take away their only chance to temper awful policies-to become "desk mitigators." Yet mitigation is often the flip side of perpetration: to implement an evil policy, but try to make it less bad, is still implementing an evil policy. Furthermore, to stay in the job runs two moral risks. First, I may become inured to evil, with my own judgment eroded by those around me, so that the abnormal becomes normalized and I lose the capacity to tell right from wrong. Second, I may be normalizing evil in the eyes of others and perhaps corrupting their judgment. Seeing me at my desk day after day, going about business as usual, contributes to smudging the line between the routine and the pathological in their minds. The two risks mirror each other: together, we move the moral baseline and warp each other's judgment.

What is a conscientious official to do? Stay or quit? A parallel dilemma faces the conscientious person who is not yet in government but gets a job offer that may entangle her. Should she take the job hoping to do good, or is she fooling herself?

Hannah Arendt, reflecting on the swift collapse of public morality in the early days of the Third Reich, offered a stern answer: in politics, obedience is supportmeaning that whether you like it or not, staying in the regime supports it. ${ }^{2}$ And, she warns, "those who choose the lesser evil forget very quickly that they chose evil." 3 Get out and go home.

Is she right, or is her stance "germ-proof moralism," as Arendt puts the objection against herself?" This is an impossible question to answer in the abstract. In this Article, I approach it through two case studies of lawyers who held important posts in the Third Reich, acted as desk mitigators, and saved lives. One of them, Count Helmuth James von Moltke, is a famous martyr of the anti-Hitler resistance, the Widerstand. The other, Bernhard Lösener, is a more problematic figure-an

1. "Desk perpetrator" is not a common term in the United States, although we have no trouble understanding the concept. It has become a commonplace term in Germany (the German word is Schreibtischtäter), a byproduct of that country's efforts to come to terms with bureaucratic murder during the Nazi regime. On the history of the term and its spillover into popular usage, see Dirk van Laak, The Trope of the Schreibtischtäter in Postwar German Discourse (manuscript).

2. See Hannah Arendt, Personal Responsibility Under Dictatorship, in RESPONSIBILITY AND JUDGMENT 17 , 4647 (Jerome Kohn ed., 2003) [hereinafter ARENDT, Personal Responsibility]; HanNah ARENDT, EICHMANN IN JERUSALEM: A REPORT ON THE BANALITY OF EVIL 279 (rev. ed. 1963) [hereinafter ARENDT, EICHMANN IN JERUSALEM]; Hannah Arendt, Thinking and Moral Considerations: A Lecture, in RESPONSIBILITY AND JudGMENT 17, 46-47 (Jerome Kohn ed., 2003) [hereinafter ARENDT, Thinking and Moral Consideration].

3. ARENDT, Personal Responsibility, supra note 2 , at 36 .

4. Id. 
enigma, in the words of one historian. ${ }^{5}$ Lösener was not just any lawyer in the Reich's civil service. He was the Interior Ministry's Judenreferent-its legal specialist on the Jews, that is, the persecution of the Jews, and seen in one light he qualifies as a paradigmatic desk perpetrator. Yet he too understood himself as a hero of the resistance. Could it be true, or is it an epic case of self-deception and self-flattery?

My inquiry in this paper is similar to the admirable "moral biography" of SS (Schutzstaffel) Judge Konrad Morgen by the philosophers Herlinde Pauer-Studer and J. David Velleman: "a case study of how one man's moral consciousness coped or failed to cope with an immoral world." ography, each piece much more compressed than Pauer-Studer and Velleman's book, that aims to test Arendt's answer to the question "stay or quit?" and her diagnosis of the moral perils of staying. It is also a study of government lawyers' ethics in times when a nation's leaders have contempt for the rule of law.

I begin by setting out the dilemma by means of a kind of fable with contemporary resonance. Next, I present Arendt's argument. Then I turn to Lösener and Moltke. In the final sections, I reflect on the morality of the choices they made, posing questions inspired by Chiara Lepora and Robert Goodin's recent philosophical study of complicity. ${ }^{7}$ Finally, I return to Arendt's theses-which, I conclude, are too stark and too simple.

\section{A FABLe ABout Yesterday AND TODAY}

During law school, you realized that the private practice of law was not for you. You did well as a student, and after graduating you were pleased to be offered a government job. It was a time of turmoil as the country emerged from a costly war and a devastating economic crisis. As a patriot, you hoped to do your bit in restoring effective government.

The incumbent government was far from the one you wanted. You were a conservative who believed the country needed strong leadership from the right. The current government was far too liberal, and it was weak in the face of the nation's enemies. Hopefully, it would soon be out of power, and meanwhile you would do your job conscientiously and bide your time.

5. See Karl A. Schleunes, The Enigma of Bernhard Loesener-Nazi Bureaucrat, in LEGISLATING THE Holocaust: The Bernhard Loesener Memoirs and Supporting Documents 3 (Karl A. Schleunes ed., 2001).

6. Herlinde Pauer-Studer \& J. David Velleman, Konrad Morgen: The Conscience of a Nazi JUDGE xii (2015). The SS (Schutzstaffel or "security squadron") was the Nazi Party's elite security and military unit, and the one most responsible for carrying out the mass murder of civilian populations. See id. at 12.

7. ChiARa Lepora \& Robert E. GoOdin, ON COMPlicity AND COMPROMISE (2013). The other major book-length philosophical study of complicity, Christopher Kutz's work of that title, does not address the issue of participating in a wrongful enterprise in order to mitigate its wrong from within. CHRISTOPHER KUTZ, COMPlicity: Ethics ANd LAW FOR A COLlective AGe (2000). 
History and politics work in peculiar ways. To your astonishment, a sulfurous populist began burning his way through the conservative coalition, and he quickly became the man of the hour-far and away the most commanding politician on the right. He was, to say the least, not the man you would have chosen, or even taken seriously. He was a coarse and vulgar demagogue, who appealed to the lowest sentiments of his political base at tumultuous mass rallies-just the opposite of the conservatives whom you admired. He spoke the language of rage; he trafficked in lies and conspiracy theories. And his talk about minority groups was vicious and paranoid. He wanted to expel them or worse; it disgusted you that his base lapped it up. To your dismay, when his most thuggish followers committed acts of violence, he refused to condemn them.

And yet, you couldn't help agree with him that the current government was wrecking the nation. His talk about making the country great again resonated with you, even if he seemed more like an egomaniac than a genuine conservative.

In any case, the winds were obviously blowing his way, and people you admired began to fall in line behind him. Your politically savvy friends reassured you that if he was elected, he would be easy to rein in. As for his most hateful and violent promises - these were no more than electioneering rhetoric. Even if he halfway believed his own slogans, he would never be able to bring them off. Probably, he wouldn't even try.

You joined his camp. Much as the leader repelled you, you had to admit he was a fighter. He was the only politician with the guts to speak the truth about the disasters that the political class was inflicting on the country.

He won the election. It now seemed that your decision to join his team was providential: as he swiftly moved to clean house in the government agencies, not only did you keep your job, you got a promotion. True, it was not a job you especially liked: you were placed in the agency dealing with the minority crisis, and that happened to be the most fevered part of the leader's program. And, to your dismay, he quickly proved that he really would try to keep his radical promises-and that he couldn't be controlled behind the scenes by establishment conservatives.

It almost made you want to quit. And yet, most of your colleagues, including your supervisor, were decent, intelligent, conscientious people-the kind of people you were proud to work with. True, the political appointees down the hall were zealots with no commitment to the agency's mission or to the rule of law. They got a kick out of their leader's open contempt for morality. But the contrast only reassured you about your colleagues - they were not like the zealots in the executive suite. They were people like you. And if you quit, who would replace you? Probably some ignorant radical. Not only would you be letting down your colleagues by quitting, you would be letting your country down.

So you stayed. It led to uncomfortable moments. In meetings and conferences you couldn't speak openly against the new government's extreme initiatives: all that would accomplish is freezing you out of the loop. To stay in the loop, you 
would have to be indirect, conciliatory, even a little dishonest. You would have to play along.

Nor could you overtly sabotage agency actions you disagreed with. Not only would that violate your professional duty, it would be self-defeating. You would swiftly be out of a job, and that would put your colleagues in a bind: support you or renounce you? In a very personal way, you would have betrayed them. Inside the agency, you could try to mitigate its most radical initiatives. Outside, you could do nothing to slow down the juggernaut.

That's what you told yourself. In the day-to-day work, though, it was sometimes hard to tell whether you were sanding the sharp corners off the leader's agenda, or the agenda was sanding off yours. With the passage of time, radical measures began to seem less radical—not only to you, but to your colleagues as well. When you looked around the conference table, nobody seemed to push backothers' obedience was complacent, even bovine. ${ }^{8}$ Of course, to be candid, you were not exactly fighting it either. Maybe others were taking cues from you just as you were from them. Did that make you all complicit? An uncomfortable thought, but one that troubled you less as time went on.

Then came a big moment in your career. You got a call at home from your boss. The leader wanted to announce major legislation at a political rally-but, in his typically chaotic way, he had never told anyone to draft the legislation. Time was short. Would you fly to where the rally was going to be held? Drafting would be a grueling job: bring your toothbrush and a change of clothes, and expect an all-nighter or even two. Your boss warned you that the radicals would be there too; he did not need to add that this would be your chance to ward off their extreme proposals. And, the boss added, the leader himself would be reading your drafts, in real time.

Every ambitious lawyer you've ever met in government service would see this as a dream opportunity: to make history, to make new law less bad than it might be, to work at the center of power. To be in the room where it happens ...

This little fable could be set in many places and many times. It could happen yesterday or tomorrow, here or elsewhere. It could be happening now, in any of a dozen countries. The story, or variations on it, might fit many officials, civilian and military. I can picture many lawyers I've met seeing it that way as they pack their overnight bag. Our imaginary protagonist is a conservative who shares some of the leader's aims - but of course a civil servant from the left would face the same "stay or quit?" dilemma in an even more excruciating form. Some who stay on the job may be unsung heroes who spare the world some cruelty and misery.

8. Cf. Chuck Park, I can no longer justify Longer Justify Being a Part of Trump's 'Complacent State.' So I'm Resigning, WASH. POST (Aug. 8, 2019), https:/www.washingtonpost.com/opinions/i-can-no-longerjustify-being-a-part-of-trumps-complacent-state-so-im-resigning/2019/08/08/fed849e4-af14-11e9-8e77-03b30 bc29f64_story.html [https://perma.cc/Q8MR-AB24]. 
Others might start as honorable public servants but gradually allow their souls to be eaten by the soul-cannibal at the top. ${ }^{9}$ Some "desk resisters" will, with eyes wide open, become "desk perpetrators," at least some of the time, because signing off on lesser evils is the price of admission to the room where it happens. Their own souls may be an unavoidable part of that price, whether they recognize it or not. (Machiavelli recognized it when he wrote "I love my native city more than my soul.,"10)

The story I've told can happen only under very particular political circumstances, so the moral issues are not exactly timeless. But the issues are by no means tied to a single, unique time or place. As it happens, we can tie some of this story to at least one singular time and place. The time is 1935, and the place is Berlin, Germany. The story is loosely modeled on how Bernhard Lösener, age fortyfour, boarded a flight to Nuremberg to draft the "Law for the Protection of German Blood and German Honor" and the "Reich Citizenship Law," commonly known as the Nuremberg Laws.

\section{Hannah AREndT's Moral ARgument}

Stories like the fable I've just told preoccupied Hannah Arendt, and her analysis of the moral dilemmas it raises will focus our discussion.

Of course, Arendt is best known for the potent phrase "banality of evil" to describe Adolf Eichmann. ${ }^{11}$ What she saw in Eichmann was an otherwise ordinary bureaucrat so shallow and thoughtless that he was unable to tell right from wrong. Leave aside whether she got him wrong, as some historians think. ${ }^{12}$ I bring up "the banality of evil," and the case of Eichmann, only to make a simple observation: the protagonist of our fable is not Eichmann, as Arendt depicts him. Our protagonist is a thinking person who reflects on her own motives, rejects the hatemongering of the leader, doesn't want to become an enabler, and - at least at first-resists the leader's assault on the rule of law. If, by the end, her soul has

9. See, e.g., James Comey, How Trump Co-opts Leaders Like Bill Barr, WASH. POST (May 1, 2019), https:// www.nytimes.com/2019/05/01/opinion/william-barr-testimony.html [https://perma.cc/PDL8-RTWL] ("Of course, to stay, you must be seen as on his team, so you make further compromises. You use his language, praise his leadership, tout his commitment to values. And then you are lost. He has eaten your soul.").

10. Niccolò Machiavelli to Francesco Vettori, April 16, 1527, in 2 MACHIAVELLI: The ChIEF WORKS AND OTHERS 1010 (Allan Gilbert trans., 1965). As Arendt reminds us, Machiavelli wrote in an era that believed in a literal Heaven and Hell. See HANNAH ARENDT, On REVOLution 290 n. 19 (1965).

11. Eichmann (1906-1962) was an SS lieutenant colonel who bore primary responsibility for organizing the ethnic cleansing of Jews from Austria and Czechoslovakia, and later the transport of European Jews to death camps. He escaped to Argentina after the war. In 1960, Israeli agents captured Eichmann in Argentina and brought him to Jerusalem to stand trial. He was convicted of crimes against the Jewish people and hanged. Arendt covered the Eichmann trial for The New Yorker magazine, publishing her articles as a book. See generally ARENDT, EICHMANN IN JERUSALEM, supra note 2. Eichmann is the archetypal desk perpetrator. Van Laak, supra note 1 , at 5 .

12. See, e.g., David Cesarani, Becoming Eichmann (2007); Deborah E. Lipstadt, The Eichmann Trial (2011); Bettina Stangneth, Eichmann Before Jerusalem: The Unexamined Life of a Mass MuRderer (Ruth Martin trans., 2014). 
been eaten, it happened against her best intentions. If she winds up as a desk perpetrator who has lost the ability to tell right from wrong, it wasn't because of thoughtlessness. It was more like deliberately swimming out to sea in a rip tide, determined not to be caught in an undertow, but getting dragged out to sea, nonetheless.

Arendt wrote about these phenomena as well. In "Personal Responsibility Under Dictatorship," among her most personal essays, and again in the lecture notes published posthumously as "Some Questions of Moral Philosophy," she writes bitterly about the mysteriously swift moral collapse of Germany in the early days of the Third Reich, and how it had taken her by surprise. ${ }^{13}$

It wasn't the Storm Troopers who surprised her; thugs are thugs. Rather, it was the unexpected betrayals by people she and her peers thought were friends. She dates the betrayal to the Nazi policy of "coordination" (Gleichschaltung) under which all the main organizations in government and civil society would be placed under Party control-a program executed over the first twenty months of the Third Reich. ${ }^{14}$ The civil service was "coordinated" almost immediately, with the 1933 "April Law" that kicked out the non-Aryans (meaning the Jews). ${ }^{15}$ Then came the rest, as Richard Evans explains:

Every national voluntary association, and every local club, was brought under Nazi control, from industrial and agricultural pressure groups to sports associations, football clubs, male voice choirs, women's organizations-in short, the whole fabric of associational life was Nazified.... Existing leaders of voluntary associations were either unceremoniously ousted, or knuckled under of their own accord. Many organizations expelled politically leftish or liberal members and declared their allegiance to the new state and its institutions. ${ }^{16}$

Rank-and-file members faced a moral choice, a gut check: stay or quit? Moderates in radical parties face the same choice today. For most, the answer was: stay. That began the betrayal, whether they recognized it or not.

In Arendt's eyes, these were people who raised a finger to test the prevailing winds, and concluded that the wind of History was blowing in Hitler's direction. Who am I to fight History? Who am I to judge? Who am I to blow against the wind? ${ }^{17}$

13. See ARENDt, Personal Responsibility, supra note 2, at 17,49

14. See id. at 24; Hannah Arendt, Some Questions of Moral Philosophy, in RESPONSIBILITY AND JudGMENT 54 (Jerome Kohn ed., 2003) [hereinafter ARENDT, Some Questions].

15. Formally, the Law for the Restoration of the Professional Civil Service, April 7, 1933-enacted two months after Hitler seized power. See Gesetz zur Wiederherstellung des Berufsbeamtentums vom 7 April 1933, Reichsgesetzblatt 175, § 3(1) (1933). For an English translation see Schleunes, supra note 5, at 154.

16. Richard J. Evans, THe Third Reich in POWER (2005).

17. See ARENDT, Personal Responsibility, supra note 2, at 24 . Arendt is especially bitter about "the matterof-course collaboration from all strata of German society, including the older elites which the Nazis left untouched, and who never identified themselves with the party in power." ARENDT, Some Questions, supra note 14 , at 53 . 
Plainly, her diagnosis is unforgiving and unflattering. Might there be less ugly explanations? For example, some people reassured themselves that staying in their jobs and organizations was the lesser evil. If I quit, they said, imagine who would take my place. Leaving would be irresponsible. ${ }^{18}$

Arendt will have none of it. The logical consequence of such reasoning is the outrageous accusation many Germans leveled against returning refugees who sought to enter post-war public life: you deserted your country in its hour of need-unlike us, the "responsible" ones who stayed behind. ${ }^{19}$ At best, this was pathetic self-deception and self-flattery; at worst, it was a coverup by desk perpetrators pretending they were resisters. German Chancellor Konrad Adenauer himself quipped that there "were seemingly more people involved in the July plot [to assassinate Hitler] than people living in Germany at the time." ${ }^{20}$ Perhaps unfairly, Arendt treats this hokum as a reductio ad absurdum of the proposition that quitting would be irresponsible, while staying on was the responsible thing to do.

To those whose defense was that they obeyed outwardly, but inwardly they never supported the Nazis, I have already indicated Arendt's blunt answer: in politics, obedience is support. Suppose that at the moment of "coordination" all these self-proclaimed non- or anti-Nazis had stayed home. Not violently or publicly resisted, which might have landed them in a concentration camp, but simply stayed home. The regime would have collapsed. Instead, they played along. ${ }^{21}$

She might have added: obedience is support because by going about their daily routines, Germans reinforced in each other the sense that nothing too outrageous was taking place. They mutually normalized the abnormal. This is one interpretation of the "bystander effect": facing an ambiguously alarming situation, we check whether others are alarmed. We look up and look around. They do the

18. See, e.g., ARENDT, Personal Responsibility, supra note 2 , at 34

19. The most famous of the refugees to attract this political slander was Willy Brandt, who fled to Norway in 1933. After the war, he returned to Germany and became mayor of Berlin and, eventually, the West German chancellor. See Dr. Wolfgang Schmidt, SPD Politician in Divided Berlin, WILLY BRANDT BIOGRAPHY, https:// www.willy-brandt-biography.com/spd-politician-in-divided-berlin [https:/perma.cc/W63Z-DLNC] (last visited June 15, 2021); Dr. Wolfgang Schmidt, Governing Mayor and Candidate for Chancellor, WILLY BRANDT BIOGRAPHY, https://www.willy-brandt-biography.com/governing-mayor-and-candidate-for-chancellor [https:// perma.cc/T38V-NVX9] (last visited June 15, 2021). An example of someone criticizing the refugees for supposedly ducking responsibility is the German writer Frank Thiess. Responding to a post-war radio broadcast about German guilt by the exiled writer Thomas Mann, Thiess lashed out at Mann. He argued that writers like him who remained in Germany as "inner emigrants" were morally finer than those, like Mann, who observed the tragedy from "the best seats" of physical exile. See Moray McGowan, German Writing in the West (1945-1990), in The Cambridge History of German Literature 443 (2000) (Helen Watanabe-O'Kelly ed., 2000). The term "inner emigrant," meaning those who remained in Germany but mentally dissociated themselves from the regime and its supporters, has become common in literary studies. See, e.g., FLIGHT OF FANTASY: NEW PERSPECTIVES ON INNER EMigRATION IN GERMAN LiTERATURE 1933-1945 (Neil H. Donahue \& Doris Kirchner eds., 2003).

20. Thomas Karlauf, Stauffenberg: Porträt eines Attentäters 26 (2019).

21. See ARENDT, Personal Responsibility, supra note 2, at 47. 
same. The result: everyone goes on about their business, halfway reassured that things aren't as bad as they appeared at first glance. ${ }^{22}$

In politics, when everyone goes about their business, everyone looks like a supporter regardless of their unspoken opposition. To borrow a label from Lepora and Goodin's philosophical study of complicity, this is "complicity by consorting." 23 Why complicity? Because consorting with wrongdoers looks like condoning or approving their actions, which might influence others. As Arendt was wont to say: in human affairs, appearance is reality. ${ }^{24}$ Obedience is support because it shakes the confidence in their own judgment of those contemplating disobedience. When people around them look like supporters, it undermines their confidence that disobeying is the right thing to do. When the wind of History changes direction, and those around you trim their sails, isn't it sheer hubris for you to keep tacking in the old direction? Maybe the obedient people around me are right and I'm wrong.

It was with such phenomena in mind that Arendt spoke of "the almost universal breakdown, not of personal responsibility, but of personal judgment in the early stages of the Nazi regime." 25 On a more extreme scale, Eichmann described his "Pontius Pilate feeling" when he attended the 1942 Wannsee conference that planned the murder of the Jews. ${ }^{26}$ When he saw the eminences of the Third Reich accept the plan, he felt cleansed of responsibility. "As Eichmann told it, the most potent factor in the soothing of his own conscience was the simple fact that he could see no one, no one at all, who actually was against the Final Solution."27

By "judgment," Arendt always means the ability to judge particulars without appealing to general rules. She thought that the trouble with basing morality on rules is that when the rules change, as they did in the early days of the Third Reich, rule-followers change along with them. ${ }^{28}$ That is the fateful step onto the slippery slope: "this early moral disintegration in German society, hardly

22. John M. Darley \& Bibb Latané, Bystander interventions in emergencies: Diffusion of responsibility, $8 \mathrm{~J}$. PeRSONALITY \& SOC. PSYCH. 377 (1968).

23. LEPORA \& GOODIN, supra note 7, at 49-50. They caution that consorting is only a form of complicity if it makes a causal contribution to the principals' wrongdoing, for example by making the principal think his consorts approve of what he is doing. The phenomenon described here is slightly different: the official's continuing in her job contributes causally by making it harder for other officials to perceive that the course of action is wrong.

24. Hannah Arendt, The Life of The Mind 19 (1978) [hereinafter Arendt, The Life of the Mind]; Arendt, On Revolution 94 (Viking Press ed., 1965) [hereinafter Arendt, On Revolution]; Arendt, The Human Condition 199 (1958) [hereinafter AREndt, The Human Condition].

25. ARENDT, Personal Responsibility, supra note 2, at 24 . I have analyzed in greater detail the mechanics by which judgment becomes corrupted and the social psychological evidence that supports that analysis. David Luban, Integrity: Its Causes and Cures, 72 FORDHAM L. REV. 279 (2003).

26. ARENDT, EICHMANN In JERUSALEM, supra note 2, at 114. Matthew 27:24.

27. ARENDT, EICHMANN IN JERUSALEM, supra note 2, at 116,126. Even so, he lost all Arbeitsfreude, joy in his work-for four weeks. Id. at 31. Arendt acidly comments that now we know how long it takes to destroy the conscience of the "ordinary man." $I d$. at 95.

28. AREnd, Personal Responsibility, supra note 2, at 44; ARENDT, Some Questions, supra note 14, at 13839. 
perceptible to the outsider, was like a kind of dress rehearsal for its total breakdown, which occurred during the war years." ${ }^{29}$ In Eichmann in Jerusalem, she speaks in even broader terms of "the moral collapse the Nazis caused in respectable European society-not only in Germany but in almost all countries." ${ }^{30}$ And in "Some Questions of Moral Philosophy" she adds, ominously, that the equally swift conversion of the Germans back to non-criminal morality after the war should not make us more confident about morality. ${ }^{31}$

Arendt, as I have mentioned, rejects a morality of general rules in times of moral emergency when the conventional rules themselves have become suspect or downright corrupt. ${ }^{32}$ Nevertheless, her argument suggests rules of thumb for those facing the dilemmas raised in our fable. In my words (not hers):

1. Don't participate. No one is asking you to be a hero and a martyr; just go home.

2. Don't dodge responsibility by protesting that inwardly you were an opponent. "Inwardly" doesn't count.

3. Don't justify participation by saying the next person would be worse.

4. Don't deceive yourself into thinking you will keep your moral judgment intact. You will be changed.

5. Don't flatter yourself by criticizing those who refuse to participate as irresponsible, while you shouldered the burden of working in the system. Shouldering guilt doesn't make you less guilty.

6. Don't mistake rule-following for morality. Think and judge for yourself.

Arendt is aware that those who take her rigorist view will be accused of "germproof moralism ..., of being unwilling to dirty their hands." ${ }^{33}$ Her response: "Politically, the weakness of the argument has always been that those who choose the lesser evil forget very quickly that they chose evil." ${ }^{34}$

\section{LÖSENER AND MOLTKE: A DOUBLE MORAL BIOGRAPHY}

Arendt's claims about self-deception and moral collapse are factual judgments, and my aim here is to examine them factually. The test cannot be a broad empirical study of whether public officials who face dilemmas of participation are

\footnotetext{
29. ARENDT, Personal Responsibility, supra note 2, at 24-25.

30. ARENDT, EICHMANN IN JERUSALEM, supra note 2, at 124-25.

31. ARENDT, Some Questions, supra note 14 , at $54-55$.

32. Id. at 104; see also ARENDT, Thinking and Moral Considerations, supra note 2, at 188-89 (arguing that "the faculty to judge particulars without subsuming them under ... general rules ... may prevent catastrophes, at least for myself, in the rare moments when the chips are down"). Her vivid illustration of moral emergencies where conventional rules are thrown radically into question is life under totalitarianism. "I am alluding, of course, to what happened in Nazi Germany and, to some extent, also in Stalinist Russia, when suddenly the basic commandments of Western morality were reversed: in one case, 'Thou shalt not kill'; in the other, 'Thou shalt not bear false witness against thy neighbor." ARENDT, THE LIFE OF THE MIND, supra note 24, at 177.

33. ARENDT, Personal Responsibility, supra note 2, at 36.

34. Id.
} 
fooling themselves by thinking they will do good and not become corrupted. Obviously, gathering and evaluating that kind of information is impossible. Instead, I want to look at two case studies. In line with Arendt's narrative and my own interest in the legal profession, I have chosen two noteworthy lawyers who stayed on the job in the Third Reich.

I make no claim that Lösener and Moltke are representative choices. Both are notable historical figures, which automatically makes them unrepresentative functionaries in the Third Reich. The reason for picking them is that both might well stake claims to accomplishing lesser evils-a self-vindication Lösener, for one, defended to his dying day. ${ }^{35}$ Yet either or both might have been fooling themselves, as Arendt seems to have thought - even about Moltke, who is a revered figure. ${ }^{36}$ Which is it?

Obviously, my earlier fable is not meant to be (only) about Nazi Germany. Some readers may object that drawing Nazi analogies to present populist regimes is a cheap debater's cliché that rests on a monstrously false assumption of moral equivalence. ${ }^{37}$ So let me say loud and clear: no moral equivalence! Today's demagogues are not Hitler, and they are not mass murderers or military aggressors; their states are not criminal states. ${ }^{38}$ My claim is one of structural similarity of the moral dilemma facing functionaries: to stay or not to stay on the job? If the fable served its purpose, the similarity should already be apparent. ${ }^{39}$

Examining these cases is relevant for another reason. If it turns out that Arendt is wrong, and there was room to do good even serving in the Third Reich, it would follow that she is wrong about serving in less evil and repressive regimes. If so, the accusation of germ-proof moralism sticks. ${ }^{40}$ If she is right in the Third Reich

35. See infra text accompanying note 60 .

36. ARENDT, EICHMANN IN JERUSALEM, supra note 2, at 99-100. Arendt paints an unflattering portrait of the German resistance, including Moltke.

37. A version of Godwin's Law holds that anyone who introduces Hitler or Nazi analogies into a discussion of anything else automatically loses. Journalist Zach Beauchamp notes that "usually, comparisons between Donald Trump's America and Nazi Germany come from cranks and internet trolls." Zack Beauchamp, A leading Holocaust historian just seriously compared the US to Nazi Germany, VoX (Oct. 5, 2018), https://www. vox.com/policy-and-politics/2018/10/5/17940610/trump-hitler-history-historian/ [https:/perma.cc/8DNVUMSF].

38. Well, some are.

39. It was apparent to one lawyer in the U.S. Department of Justice who reflected that if she stayed in her job "she would have been the kind of official who pushed for carve-outs in the Nuremberg Race Laws, preserving citizenship rights for Germans with only partial Jewish ancestry. She would have felt that this was better than nothing - that it justified having worked in the regime from the beginning." The lawyer is Erica Newland, who served in the Office of Legal Counsel of the U.S. Department of Justice. Quoted in George Packer, How to Destroy a Government, THE ATLANTIC, Apr. 2020, at 60. Newland knew the career of Bernhard Lösener. She has subsequently written on the issue of complicity. Erica Newland, I' $m$ Haunted by What I Did as a Lawyer in the Trump Justice Department, N.Y. TIMES, Dec. 20, 2020, https://www.nytimes.com/2020/12/20/opinion/ trump-justice-department-lawyer.html [https://perma.cc/8SJM-C7G]. See also Anne Applebaum, History Will Judge the Complicit, THE ATLANTIC (July/Aug. 2020), https://www.theatlantic.com/magazine/archive/2020/ 07/trumps-collaborators/612250/ [https://perma.cc/88WM-ERL9]. Applebaum's powerful article draws parallels between the present and East Germany under the Communist regime.

40. ARENDT, Personal Responsibility, supra note 2, at 36. 
cases, we can still ask what features of their service make her right. And if, as I think, the cases are not straightforward, there may be something to learn by asking why.

A key question is how much freedom of action and resistance officials enjoyed in the Third Reich. Let me introduce a label for this kind of freedom. Engineers use the word "tolerance" to denote the permitted limits of variation within precision machinery. It seems like an apt term. Tolerance in this sense does not refer to official policies of toleration-no such policy existed in Hitler's governmentnor does it refer to broad-minded "tolerant" attitudes. As I use it here, it refers to an official's maneuvering room for protest, resistance, and pushback. To avoid the other connotations, I will use the equivalent German word Spielraum, introduced here as a term of art for oppositional maneuvering room. ${ }^{41}$ How much Spielraum do officials have before they lose their jobs or their necks? If it turns out that even in a totalitarian regime resisters have Spielraum to do genuine good, it may follow that in more ordinary regimes, where the Spielraum is wider, the pursuit of the lesser evil need not be the kind of self-deception that Arendt thinks is tantamount to moral collapse. ${ }^{42}$ So a study of Spielraum under Hitler seems like an entirely proper way to test her argument.

\section{A NOTE ON SOURCES}

Whenever possible, I will allow Lösener and Moltke to speak in their own voices. Quotations from Lösener come from three main sources. The first is his own memoir, titled At the Desk of Racial Affairs, Reich Interior Ministry. ${ }^{43}$ Written by Lösener in 1950, this memoir was published in a German periodical in 1961, nine years after his death. It was published because of two political developments: an

41. Etymologically, Spielraum means "space for play," and it is commonly translated as "scope"; but it also means "tolerance" in the engineering sense. I learned this use of the word from the German philosopher and sociologist Eduard Baumgarten (1898-1982), who planned to write a memoir of his years in the Nazi Party, to be titled Spielraum unter Hitler. I spent a few days with him in the summer of 1976. Baumgarten explained to me that he meant the word in its engineering sense. The memoir would describe what it was like to be "a mid-level man in Hell." He died before completing it. Baumgarten was not a Nazi by conviction-rather, he joined the Party to save his university career after Martin Heidegger denounced him as a liberal democrat (Baumgarten believed it was out of personal pique). During the war, Baumgarten served as a liaison between Party and army, a high enough post that he had to go through post-war denazification proceedings. See David Luban, $A$ Conversation about Heidegger with Eduard Baumgarten, in BEREL LANG, HEIDEGGER's SILENCE 101-11 (1996).

42. Then again, it may not. A law professor I know was once a U.S. government tax lawyer. When the Reagan administration wanted to allow religious universities to engage in race discrimination without losing their tax-exempt status, she objected that it was illegal. She was immediately fired. She had no Spielraum.

43. I use the English translation, in Schleunes, supra note 5. Hereafter, Jewish Desk refers specifically to Lösener's memoir, not the other documents in Schleunes, supra note 5. Along with Schleunes's excellent editor's introduction to LH, the best secondary source on Lösener is CORNELIA ESSNER, DIE 'NÜRNBERGER GESETZE'ODER DIE VERWALTUNG DES RASSENWAHNS: 1933-45 (2002), https://digi20.digitale-sammlungen.de/ de/fs1/object/display/bsb00044208_00129.html?contextSort=sortKey\%2Cdescending\&contextRows=10\& context=Loesener [https://perma.cc/6UGZ-VD4X] (providing a searchable electronic copy from the Bayerische Staatsbibliothek). 
East German propaganda campaign highlighting the Nazi past of West German government officials, and the Eichmann trial, which spotlighted the extent to which West Germany ignored and protected Third Reich "desk perpetrators." Chancellor Konrad Adenauer's chief of staff Hans Globke was the highestprofile, and therefore irresistibly juicy, target of East German propaganda-and Globke had worked closely with Lösener in the Office of Jewish Affairs. Lösener's memoir was published by Globke supporters in the context of a campaign to defend Globke. ${ }^{44}$

The second source is Lösener's testimony at the Nuremberg trial of his supervisor, Dr. Wilhelm Stuckart, State Secretary of the Interior Ministry. ${ }^{45}$ Officially, Lösener was a witness for the prosecution, but his testimony is arguably more exculpatory than not. Stuckart was convicted of war crimes and sentenced to time served (three years and ten months).

Third is the transcript of Lösener's interrogation preceding the Stuckart trial, and his accompanying affidavit, both in the Yad Vashem archives. ${ }^{46}$ To a lesser degree I also draw on Lösener's legal writings. They are not autobiographical, but they offer some important clues about his personal outlook.

Moltke's testimony is also drawn from three main sources. The first is his collected letters from the war years to his wife, Freya. ${ }^{47}$ Moltke wrote her as often as he could and she saved the letters when, after the war, she fled from Soviet "protection" of their family estate, first to South Africa, then-when she found apartheid unbearable-to the United States. Freya von Moltke died in Vermont in

44. See EsSNER, supra note 43, at 113-15; MARIO KeßLER, Die SED Und DIE JUdEN - ZwiSCHEN RePression und TOleranz 130 (1995); see also AnNetTe WeInke, LAW, History and Justice: Debating German State Crimes in the Long Twentieth Century (2018); Peter Monteath, The German Democratic Republic and the Jews, 22 GERMAN HIST. 457 (2004). For a quick overview, see Klaus Wiegrefe, West Germany's Efforts to Influence the Eichmann Trial, SPIEGEL INT'L (Apr. 15, 2011, 5:35 PM), https://www. spiegel.de/international/world/the-holocaust-in-the-dock-west-germany-s-efforts-to-influence-the-eichmanntrial-a-756915.html [https://perma.cc/67RZ-KA4H].

45. The English translation of the transcript is included in Schleunes, supra note 5, at 112-52. The case was United States v. Weizsäcker, the so-called "Ministries" or "Wilhelmstrasse" trial, conducted by the United States in Nuremberg in 1948 during the second round of Nuremberg trials. Stuckart, as Secretary of State in the Interior Ministry, was one of several ministerial officials charged with crimes against peace and crimes against humanity. OFFICE OF MILITARY GOVERNMENT FOR GERMANY (U.S.), INDICTMENT (11-15-1947), https:// digitalcommons.law.uga.edu/cgi/viewcontent.cgi?article=1000\&context=nmt11 [https://perma.cc/6K83-DYLD] (last visited June 15, 2021) (see especially IIT 10,34, and 48).

46. Nuremberg interrogation transcript of Lösener (Oct. 13, 1947), Yad Vashem: The World Holocaust Remembrance Center, https://documents.yadvashem.org/index.html?language=en\&search=advance\&su value=Loesener\%20Bernhard\&su_type=literal\&GridItemId=3731736 [https://perma.cc/U2RH-GZPL] (last visited June 15, 2021); Aff. by Bernard [sic] Lösener concerning the Jewish Section in the Reich Ministry of the Interior and his efforts to gain release from his post [hereinafter Affldavit], 2 NUREMBERG 24.2.48 (NG 1944-A, B06-1605) 751, \1 (1944). His Nuremberg affidavit was subsequently submitted as evidence in the Eichmann trial. Translations are mine.

47. Helmuth JAmeS vON MOLtKe, LetTERS to FreyA 1939-1945 (Beate Ruhm von Oppen ed. and trans., 1990) [hereinafter LETTERS TO FREYA]. Freya's own memoir of the 1930-1945 period is available in English. See Freya von Moltke, Memories of Kreisau and the German Resistance (Julie M. Winter trans., 2003) [hereinafter MEMORIES OF KREISAU]. 
2010, age ninety-eight, after a career publicizing her husband's legacy and advocating political activism in dark times. A second source of quotations from Moltke is the biography written by two of his English friends, Michael Balfour and Julian Frisby ${ }^{48}$ And a third is historian Ger van Roon's anthology of Moltke's correspondence and journal entries. ${ }^{49}$

We will start with Lösener.

\section{LÖSENER AT THE JEWISH DESK}

The pivotal episode in Bernhard Lösener's legal career began late at night on September 13, 1935. Lösener, who began as a provincial bureaucrat, was now a lawyer in the Third Reich's Ministry for the Interior, and the post he held was Judenreferent (Jewish expert). As he tells the story, he had recently gotten a promotion, and that night he was celebrating with "a long and leisurely twilight drink" when, at eleven o'clock, his wife called him to the telephone. ${ }^{50}$ His boss ordered him to fly to Nuremberg early the next morning, because Hitler planned to announce major legislation at the Nazi Party rally, and the legislation was not yet drafted. Lösener went to his office to gather some papers, got a little sleep, and caught a 7 a.m. flight to Nuremberg. Over the next two days, in a chaotic environment, a team of drafters produced four versions of the legislation, ranging from most severe to most lenient, and sent all of them to the Führer for personal review. Against the Party race radicals in the room, Lösener did battle on behalf of lenience. And, to Lösener's relief, Hitler eventually chose the least severe version, which Lösener regarded "as a great success, one for which I took a certain amount of credit." ${ }^{51}$

Lösener focused especially on the definition of a Jew. Would the persecutions apply only to those with two Jewish parents, or also include Mischlinge, half- or quarter- or eighth-Jews? The lenient versions of the laws would spare Mischlinge from persecutions. That was the ground on which Lösener made his stand, fighting against Party radicals who wanted to define the category of Jews as broadly as possible so the laws would sweep in the Mischlinge as well. Lösener partly prevailed, and in subsequent rounds of decrees implementing the laws, Lösener had to fight again and again to spare the Mischlinge. It was Lösener's private war, and the basis for his claim to be a resister; in fact, he claims to have spared as many as 100,000 Mischlinge from the Nuremberg Law persecutions. ${ }^{52}$

48. Michael Balfour \& Julian Frisby, Helmuth von Moltke: A Leader Against Hitler (1972). They too draw extensively on Moltke's letters to Freya. Except when otherwise indicated, I use von Oppen's translation of letters rather than Balfour and Frisby's.

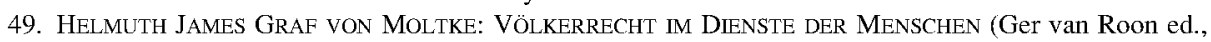
1986).

50. Jewish Desk, supra note 43 , at 46.

51. Id. at 55 .

52. Id. at $60,68,140$. 
Eventually, though, he came to a moral chasm he could not cross. Lösener learned about the mass murder of deported German Jews near Riga shortly before Christmas, 1941. "For the first time I learned that my worst fears for the fate of the deportees had come to pass-or better put, had been exceeded." ${ }^{\circ 3}$ Lösener requested and was granted a transfer to a different job, but it took months to process it, and he began his new job only fifteen months later. In the meantime, he continued working as $J$ udenreferent, after which he took a long vacation. ${ }^{54}$

Then came the July 20, 1944 bomb attempt against Hitler, and Lösener offered shelter in his home to one of the bomb plot fugitives and his wife. ${ }^{55}$ This led to his arrest and imprisonment by the Gestapo, an accusation of treason, and a likely death sentence if the war had continued. ${ }^{56}$

We are entitled to skepticism about a memoir and testimony that are so obviously self-serving. Historian Cornelia Essner, among the most knowledgeable experts on Lösener, puts it dryly: his memoir-like all autobiographies-mixes poetry and truth.$^{57}$ Historians dispute Lösener's account of the chaos in which the Nuremberg Laws were drafted. In fact there had been a lot of advance planning for the legislation, and very likely the files Lösener fetched from his office on the fateful night of September 13th contained the preparatory work. ${ }^{58}$ Notably, Lösener participated in a June 1934 meeting of a Commission on Criminal Law Reform in which a proposal to criminalize sexual intercourse between Jews and Germans was debated fiercely and at length (Lösener was against criminalization); and this turned out to be one of the Nuremberg Laws prototypes. ${ }^{59}$

Yet there is no reason to doubt the chief points of his remarkable story: that he helped draft the Nuremberg Laws, that again and again he battled Party radicals to protect the Mischlinge, that he may have saved a great many lives, and that he eventually left the job, fell out of favor, was arrested, and faced a death sentence.

Lösener had no doubt that he was a quiet hero in a bureaucratic battle fought in secret on the desolate terrain of the lesser evil, and he was sure that if he quit his job someone worse would have taken it:

53. Id. at 99. The massacre is known today as the Rumbula massacre, named after the forest outside Riga where it took place. Lösener does not mention the far larger number of Latvian Jews murdered in Rumbula Forest. Whether that is because the Interior Ministry received information only about the German Jews in its remit, or because Lösener didn't care about Ostjuden, Jews from the east, is a matter for speculation.

54. Id. at 100 .

55. Id. at 101 .

56. Id. at 102

57. See Essner, supra note 43, at 117. "Poetry and Truth" (Dichtung und Wahrheit) is, of course, the title of Goethe's autobiography.

58. See Schleunes, supra note 5, at 14-16; see also Essner, supra note 43, at 116-17 for references to historians' divided opinions. Among other grounds for doubt, nobody has found the four drafts of the law.

59. James Q. Whitman is able to give a blow-by-blow analysis of this meeting because a stenographic record was unearthed and published in 1989. Whitman also has a helpful discussion of Lösener and his ally Gürtner. See James Q. Whitman, Hitler's American Model: The United States and the Making of NAZI RACE LAW 93-110 (2017). 
I remained the pivotal point around which everything else turned. ... A zealous party member in my place would have brought additional and untold misfortune to countless people. ${ }^{60}$

As for his personal attitude toward the Nuremberg Laws, he stated, "I regarded them as an outrage every minute of the two days it took to draft them."

Yet he did draft them, and he also helped draft the terrible decrees that implemented them. Furthermore, he co-authored an official annotation of the Laws, and he wrote a law journal article about "the main problems of the Nuremberg Laws and their implementing decrees."62 Even more damningly, Lösener later drafted a letter, signed by his boss Stuckart, recommending the sterilization of all the half-Jews. Lösener defended this proposal as a horrible but necessary compromise to spare the half-Jews from death- "we had to show Heydrich and Himmler that we had different intentions [than saving lives] which had to be made rather tasty for Herr Heydrich." 63 Lösener adds that he and Stuckart had first assured themselves that the sterilization would be impossible, for technical reasons. Even so, we could easily condemn Lösener as a desk perpetrator par excellence. Even if he mitigated persecution, it was persecution that he helped set in motion.

And-by the way - what was he doing "at the desk of racial affairs, Reich Interior Ministry" (the title of his memoir) in the first place?

\section{HOW LÖSENER GOT THERE}

"I joined the NSDAP [the Nazi Party] . . because I wrongly assumed that only this party could succeed in rescuing Germany from the not-so-rosy situation in which it found itself back then." ${ }^{64}$ He joined in 1930, more than two years before Hitler took power. Lösener "found National Socialist Propaganda believable," and he hoped the Nazis could bring an end to domestic turmoil and street fighting by balancing (Ausgleich) the aims of nationalists and communist workers. ${ }^{65}$

And-stunningly - "If I may say so, I joined the Party not because of its Antisemitism, but - if I may put it this way-despite its Antisemitism, because I reassured myself with Hitler's promises that he would bring an end to the fighting and cure unemployment." 66 The lawyer who sat at the Jewish desk of the ministry in charge of persecuting Jews tells us he was an anti-antisemite.

\footnotetext{
60. Jewish Desk, supra note 43 , at 45 .

61. Id. at 52 .

62. Bernhard Lösener, Die Hauptprobleme der Nürnberger Grundgesetze und ihrer Ersten Ausfïhrungsverordnungen, 56 REICHSVERWALTUNGSBLATT 929 (1935).

63. Schleunes, supra note 5, at 141 (including an English translation of the testimony).

64. Jewish Desk, supra note 43 , at 35 .

65. Yad Vashem, supra note 46, at 4324; Affidavit, supra note 46, at 1.

66. Yad Vashem, supra note 46, at 4324.
} 
As for the "radical positions" of the Party on race questions and paramilitary violence [Volkssturms], "I took those as propaganda excesses." ${ }^{67}$ Lösener elaborated this point at the trial of Stuckart:

In the political election campaign, it was always customary that before an election took place, enormous exaggerations are voiced. I think it is like this all over the world, and it is also like this in Germany. The slogans on the platforms were exaggerated slogans which were mentioned again and again in order to get the voters over to the side of the Party, and to appeal to their baser instincts ... I myself never believed that these slogans would be adhered to so literally later on ... I was horrified by the extent to which the Party followed up its racial persecution. ${ }^{68}$

Indeed, Lösener tells us that his "disinclination" toward Hitler's race policies began even before his job at the Jewish desk-specifically, from the moment he read the April Laws of 1933 that expelled non-Aryans from the civil service. The "Aryan Clause" of the April Laws "gave me my first severe shock," and "a foreboding of evil came over me." ${ }^{69}$ He took the job anyway.

Not that he lacked prejudices against Jews. During his preliminary Nuremberg interrogation, when asked if he approved of expelling "full Jews" from the professions, he answered "No. Let me put it this way. There was misadministration in Germany because a large part of the civil service was staffed by people who apparently got their positions not because of their abilities, but because of their ties with Jews."70 "But," Lösener continued, "I disapproved of all those measures

67. Id. Literally, the Volkssturm was a national militia set up by the Nazi Party (not the army) near the end of World War II to provide last-ditch homeland defense. Obviously, this was not the pre-1933 Volkssturm Lösener is referring to. I take it he borrows the latter-day term to describe earlier right-wing paramilitaries such as the Party's Storm Troopers, in the final years of the Weimar Republic-who in turn were the successor to the right-wing Freikorps militias earlier in the Republic. When Lösener refers to the "radical position" of the Party on paramilitary violence he may have in mind a notorious telegram of support Hitler sent to five Storm Troopers who brutally battered a trade unionist to death in front of his mother and brother- the "Potempa murder," so named after the town where it took place. They were sentenced to death. VOLKER ULLRICH, HITLER: ASCENT, 1889-1939 322-23 (Jefferson Chase trans., 2016). Hitler's telegram, sent August 22, 1932, read: "My comrades! In light of this monstrously bloodthirsty verdict, I feel connected to you in boundless loyalty. From this moment on, your freedom is a matter of honor for us, and the fight against a government, under which this judgment was possible, is our duty." Id. Under Nazi political pressure, the Papen government reduced their sentence to life imprisonment. Once in power, Hitler pardoned the Potempa Five. Id. at 323. The astute reader will recall that in my earlier fable, I wrote about the hypothetical populist leader that "when his most thuggish followers committed acts of violence, he refused to condemn them." Hitler's Potempa telegram is one outstanding example I had in mind.

68. Schleunes supra note 5, at 117-18. A noteworthy fact is that Adolf Eichmann said something similar, in the memoir he wrote in prison in Jerusalem while awaiting execution: "And during the so-called NSDAP Time of Struggle, neither I nor my likeminded peers took the antisemitic program of the Party in the least bit seriously." Adolf Eichmann, GötZEN: Die AutobiogRAFie von AdOlf EichMANn 100 (Raphael Ben Nescher, 2016) (my translation); also available on the Internet at http://www.schoah.org/shoah/eichmann/goetzen.htm [https://perma.cc/2WEM-29HE], at 50-51 (Eichmann's manuscript at 28-29).

69. Jewish Desk, supra note 43 , at 36 .

70. Vashem, supra note 46 , at 4342. 
that expelled Jews generally from the civil service, the medical profession, etc. as damnably [verdammenswerte] harsh." 71

His comment about civil servants getting their jobs through Jewish connections was a commonplace of the anti-Weimar Republic right, not uniquely Nazi-something more akin to resentment-memes against affirmative action in contemporary U.S. politics. ${ }^{72}$

But there is more to the interrogator's question and Lösener's answer than meets the eye. They were fencing. To understand what they were fencing about, we must delve into disagreeable details of Nazi efforts to define who is a Jew, and therefore subject to persecution.

The 1933 April Laws defined a Jew according to a "one-fourth rule": one Jewish grandparent sufficed to make someone a Jew and cost them their civil service job. When it came time to draft the Nuremberg Laws, Party radicals like Goebbels and Lösener's nemesis Gerhard Wagner, the "Leader of Reich Physicians," wanted a "one-eighth rule": one Jewish great-grandparent made one a Jew. And Julius Streicher, the Third Reich's most vile Jew-baiter, favored a "one drop of blood rule" modeled on the race laws of the American South, which the Nazis carefully studied. ${ }^{73}$ As we've seen, Lösener's subsequent legal in-fighting against Nazi persecution centered on making anti-Jewish laws apply to as few people as possible. This would be done by restricting their scope to "full Jews," and defining a full Jew as someone with at least three Jewish grandparents, the best compromise Lösener could achieve. ${ }^{74}$ That is why the interrogator pointedly asked Lösener if he personally favored expelling full Jews from the professions. By answering "no," Lösener was trying to suggest that his later efforts to restrict anti-Jewish legislation to full Jews were a tactical maneuver, not an endorsement of Nazi racism toward full Jews.

Still, Lösener's professions of anti-antisemitism are a bit hard to swallow. His memoir, interrogation, and testimony leave out a few awkward facts. In 1920, Lösener joined a splinter Masonic lodge of Christian antisemites. ${ }^{75}$ By 1931 he was not only a Nazi Party member but a reserve Storm Trooper; and in 1931 he gave a speech to a public audience on "Races and the Jewish Question," while he was still a Weimar Republic civil servant for whom such a speech was illegal. He boasted that his speech induced most of his 450-member audience to join the

71. Id.

72. See, e.g., PETER Fritzsche, LifE AND DEATH IN THE ThIRD ReICH 87 (2008) (noting that everyday discussions of Jewish quotas, Jewish percentages, and degrees of Jewish influence were "[b]y no means . . . the monopoly of Nazi party members").

73. See Schleunes, supra note 5, at 153; WHITMAN, supra note 59, at 93-94, 98-123. Streicher was convicted of crimes against humanity in the Nuremberg trial of the major war criminals, and hanged. He was the only defendant hanged exclusively for his role in persecuting the Jews.

74. First Supplementary Decree to the Reich Citizenship Law (Nov. 14, 1935), art. I, para. 5, reproduced in English in Schleunes, supra note 5, at 156. The legal definition is a bit more complicated than the text above indicates: it also included half-Jews who practiced the Jewish religion.

75. ESSNER, supra note 43, at 119-20. 
Nazi Party. ${ }^{76}$ Essner believes it was this speech that landed him the job at the Jewish desk; his own explanation, that it was sheer happenstance, is poetry, not truth. ${ }^{77}$

Furthermore, he appears to have believed in the pseudo-science of race. In 1936 Lösener wrote a pamphlet on the Reich Citizenship Law. The pamphlet endorses the primacy of race over citizenship as "the only healthy view," and he hopes that race-independent legal conceptions of citizenship will eventually die out (but, he adds naively, not through imperialism). ${ }^{78}$ Lösener denounces the Weimar Republic's recklessness in granting citizenship to East European Jews, whose population growth was "most dangerous and pernicious for the German people." $" 79$

Yet even if Lösener harbored typical prejudices against Jews, and believed in racial pseudo-science, there is no reason to doubt that persecution of his Jewish countrymen repelled him, and I think James Whitman's description of him as "a reprehensible anti-Semite ... who later tried to whitewash his record" is too quick. ${ }^{80}$ The same pamphlet that extols race-based citizenship insists, unrealistically, that Nazi race doctrine did not place "different absolute value" on the German and Jewish "races." Rather, maintaining unmixed blood would be healthy for both peoples-it would preserve their unique characteristics and racial inheritance (Erbmasse). ${ }^{81}$ This separate-but-equal spin on Nazi race doctrine is far removed from the "master race" poison spewing from the Party and engulfing Germany; it is noteworthy that Lösener would dare put it in an official document.

One need only compare Lösener's separate-but-equal gloss with the Nuremberg Law commentary by Stuckart and Globke, who write: "Over against the doctrines of the equality of all human beings ... National Socialism sets the harsh but necessary recognition of the natural inequality and differentiation in kind among humans." ${ }^{, 2}$ By contrast, Lösener writes in a professional journal for administrative lawyers: "According to the Führer's will, the Nuremberg Laws are not measures to breed and perpetuate race hatred, but rather to signify the beginning of peaceful relations between the German and Jewish peoples. ${ }^{, 83}$ As in the

76. Id. at 122. The text of Lösener's speech is lost, if indeed he wrote it out.

77. Id. Lösener's "happenstance" explanation is in Jewish Desk, supra note 43, at 36.

78. Bernhard Lösener, Staatsangehörigkeit und Reichsbürgerrecht 3, 29 (1939) (on file with author, 41 in the facsimile in author's possession), also quoted in translation (under the mistranslated title Citizenship and the Reich's Burgher Law) in U.S. Dep't of State, Special Unit on the Division of European Affairs, National Socialism: Basic Principles, Their Application By the Nazi Party's Foreign Organization, and the Use of Germans Abroad for Nazi Aims 69-70 (1943), https://babel.hathitrust.org/cgi/pt?id=mdp.39015012927201\& view=lup\&seq=7 [https://perma.cc/4MNB-27MN] (citing Grundlagen, Aufbau und Wirtschaftsordnung des nationalsozialistischen Staates, Berlin, 1936, vol. I, group 2, no. 13).

79. Id. at 30 .

80. WHITMAN, supra note 59 , at 92 .

81. Lösener, supra note 78 , at 39 . Erbmasse can also mean 'genotype'.

82. Quoted in PAUER-STUdeR \& VelLEMAN, supra note 6, at 38.

83. Lösener, Die Hauptprobleme der Nürnberger Grundgesetze, supra note 62, at 932. My translation. 
separate-but-equal language noted above, Lösener puts an unreal benign spin on "the Führer's will." Perhaps this was wishful thinking and self-delusion, but it may also have been strategic, aiming to influence official implementation of the laws in a more lenient direction. Either way suggests that Lösener's crabbed version of anti-antisemitism (yes to racism, no to persecution) was not a postwar whitewash.

Indeed, Lösener introduces the law journal article with language artfully couched in Nazi rhetoric, but that actually says less than it seems:

These laws are the unflinching measures taken by a people to whom the coming generations are more important than the living. Therefore, the living generation must exert itself to the utmost, because the pressing dangers can still be successfully averted today. But if we do not lead the fight, our descendants will no longer be able to cope with the insurmountable difficulties. ${ }^{84}$

Racists could read this as a call to arms against the Jewish menace. But Lösener never explains what "pressing dangers" he has in mind, and the sequel makes it clear that he meant the continuing conflict between Jews and (other) Germans, which he hoped the laws would put to rest in peaceful coexistence, albeit on unequal terms.

Why was he repelled by persecution? He tells us that it was for "ethical reasons," namely "the only genuine argument, that of basic humanity or even of 'positive Christianity'." ${ }^{85}$ Here too, though, matters are more complicated, and his motives were probably more mixed than he admits. Throughout the early years of the Third Reich, the state and the Nazi Party set up competing race bureaucracies, with the Party always more radical, in line with the sentiments of the brown-shirted Party base-those Lösener dismissively calls "the brown masses." ${ }^{86}$ As historian Deborah Hertz explains,

It was in the interest of state officials that Nazi policy on the mixed-breeds be flexible and moderate. State bureaucrats wanted to maintain positive relations with the outside world during the 1930s. The state officials also tended to be less extreme in their anti-Semitism. A case in point is Bernhard [Lösener] ... The ASF [Party] functionaries opposed [Lösener's] efforts. They saw themselves as expressing the anger of radical rank-and-file party members. The ASF spoke for those who were frustrated with what in their eyes was the slow pace of Jewish persecution in the first years of the new regime. ${ }^{87}$

84. Id. at 929

85. Jewish Desk, supra note 43, at 45 ("ethical reasons"); id. at 57 ("basic humanity"). "Positive Christianity" was the Nazi Party's official version of Christianity.

86. $I d$. at 38 .

87. Deborah Hertz, The Genealogy Bureaucracy in the Third Reich, 11 JEWISH HIST. 53, 59 (1997). The ASF was the Nazi Party's Amt für Sippenforschung (Bureau of Kinship Research); it competed with the RSF, the Reichstelle für Sippenforschung, the State Office for Kinship Research. The SS established its own Race Bureau (Rassenamt) in 1931, for purposes of authenticating the Aryan purity of SS members. For further useful discussion, see Jürgen Matthäus, 'The axis around which National Socialist ideology turns': State 
So Lösener's attitudes were commonplace among state bureaucrats moved by pure pragmatism. Concern that drastic persecution might invite foreign boycotts or even intervention very likely stayed Hitler's hand as well in the early years; that would explain why the Nuremberg Laws did not come into being until $1935 .{ }^{88}$ In his backroom lobbying efforts, Lösener pressed only pragmatic arguments for narrowing the definition of Jews, because only pragmatic arguments stood a chance - and they also reflected the concerns of the bureaucracy.

More basically, I think Lösener had a lawyer's exaggerated faith in laws and rules, even though he knew better. Coupling faith in law with insider knowledge that law was irrelevant is the basic contradiction in his memoirs, and probably in his personality. He knew "with what utter contempt Hitler looked down upon government offices, professional civil servants, and especially lawyers." 89 But somehow he still believed that legalities would make a difference.

In the memoir, he argues elaborately that the Nuremberg Laws actually protected Jews against racist local officials who were running wild; and his annotation of the Nuremberg Laws echoes that theme. His annotation warns that the Laws' official definition of Mischlinge is exhaustive, and "it is impermissible to designate or treat a group other than those described above as German-Jewish Mischlinge. .. This will no longer be done in state laws or other orders and in such orders of the Party." ${ }^{90}$ And, although the Nuremberg Laws demoted Jews to second-class (non)citizenship, even second-class citizens have "an entitlement to the protection of the state regarding person, assets, professional practice, especially regarding economic activity."91

Lösener saw his efforts "as a great success .... Evil Party demands had been kept out of the law." 92 And, as a result of the Nuremberg Laws, Jews "knew now where one stood.... [A]s vile as it was, it at least provided something to hold on to, a solid foundation for the future." 93 Of course it did not, but Lösener was not alone in thinking it did. Apparently, the German Jews shared this wishful thinking that written laws would "establish a level on which a bearable relationship between the German and the Jewish people [became] possible," in the words of a

Bureaucracy, the Reich Ministry of the Interior, and Racial Policy in the First Years of the Third Reich, in Beyond the Racial State: Rethinking NAZi Germany 241-71 (Devin O. Pendas et al. eds., 2017).

88. Hertz, supra note 87 , at $67-68$.

89. Jewish Desk, supra note 43 , at 37-38.

90. Lösener \& Friedrich A. Knost, Erlaüterungen der Nürnberger Gesetze und deren Verordnungen, in DIE NÜRNBERGER GESETZE MIT DEN DURCHFÜHRUNGSVERORDNUNGEN UND DEN SONSTIGEN EINSCHLÄGIGEN VORSCHRIFTEN 51 (Lösener and Knost, eds., $5^{\text {th }}$ ed., 1942) (providing commentary on \$2(2)).

91. $I d$. at 46 (providing commentary on $\$ 1(8)$ ). By "second-class (non)citizens" I am referring to the legal category of Staatsangehöriger (national) concocted in the Nuremberg Laws, as distinct from Staatsbürger (citizen).

92. Jewish Desk, supra note 43 , at 55.

93. Id. at 54, 55. 
national organization of German Jews. ${ }^{94}$ After Kristallnacht, such wishful thinking became impossible for the Jews, but evidently not for Lösener for a few more years. ${ }^{95}$

Defensively, he writes that "the completely hellish form of the persecution of the Jews in later years became horrible reality not as a result of, but rather despite the Nuremberg Laws." He calls this "a simple statement of objective fact." ${ }^{\text {"96 }}$ It is anything but. Only a lawyer with a fairy-tale faith in legal formalities could fail to understand that laws enshrining racism would not cabin it, but rather would soften up the public for something far more extreme. To think otherwise is selfdeception and psychological stupidity. It should have been doubly astounding for a lawyer in the Third Reich. Nazi jurisprudence rejected legal formalism on principle, and substituted the "healthy feeling of the Volk" as a kind of natural law that trumps legality, especially in matters of race. ${ }^{97}$ The healthy feeling of the Volk meant the desires of Hitler and the Party, as everyone understood. Hitler did not officially abolish judicial independence until 1942, which suggests that at least some rule of law remained in the 1930s. ${ }^{98}$ But Hitler had already

94. See ARENDT, EICHMANN IN JERUSALEM, supra note 2, at 39-40 (quoting national organization of German Jews).

95. I've been told by a Berliner that many Germans now use the label 'Pogromnacht' (Pogrom Night) rather than 'Kristallnacht' or 'Reichskristallnacht' (the Night of Broken Glass, as it is usually often rendered in English) because the latter seems euphemistic. I retain 'Kristallnacht' because the newer alternative has not yet entered English.

96. Jewish Desk, supra note 43 , at 55 .

97. See the fascinating discussion of this jurisprudential turn in PAUER-STUDER \& VELLEMAN, supra note 6 , at $26-29,37-39$.

98. Hitler abolishing judicial independence: "So I expect the German judiciary (Justiz) to understand that the nation is not there for them, but they for the nation, that is, that the entire world, Germany included, shall not perish for the sake of legal formality (damit ein formales Recht lebt), but rather that Germany must live regardless of formal judicial opinions (Auffassungen) to the contrary. . . From now on I will intervene in these cases and remove judges who obviously don't understand the imperative of the hour." Adolf Hitler, Address at Reichstag (April 26, 1942); See Jens MeIerhenrich, The Remnants of the RechtsstaAt: An ETHNOGRAPHY OF NAZI LAW 153 (2018) (noting that Himmler was behind the 1942 "Justizkrise").

The issue of how lawless the Third Reich was at various times is a complex and deep one, because the forms and institutions of the Rechtsstaat-the rule-of-law state-remained at least formally intact, and a great deal of everyday law governing contracts, torts, and the like were unchanged and unaffected. This hardly mattered, however, in the setting where Lösener operated, because persecuting the Jews mattered to officials like Heydrich and Himmler, to whom law meant as little as it did to Hitler. For a recent, searching discussion of legality in the Third Reich, see Meierhenrich, supra. Meierhenrich invokes and defends the distinction between the "normative" state (roughly, the formal legal institutions) and the "prerogative" state (roughly, the Gestapo and other security forces that enforced the dictatorship). $I d$. at 182-90,245. This distinction originates with the German lawyer and theorist Enst Fraenkel, in his classic book ErNST FraENKEL, The DuAl State: A CONTRIBution to THE THEORY OF DiCtATORship (1941; republished 2018). In these terms, Lösener was a "normative state" man perpetually thwarted by the prerogative state. See also the brilliant new study of Fraenkel, Douglas Morris, Legal Sabotage: Ernst Fraenkel in Hitler's Germany (2020). SS Judge Konrad Morgen, the subject of Pauer-Studer \& Velleman, supra note 6, is an instructive case in point of the bizarre Nazi mix of legal forms and murderous content. Morgen assiduously prosecuted camp personnel for corruption and unauthorized murders-but not for the authorized murder and cruelty that were the camps' main business. He was an authentic "normative state" man in a setting where the laws were the house rules of the Inferno. 
countermanded Lösener's efforts mere weeks after the Nuremberg Laws. After Kristallnacht the handwriting on the wall could hardly have been plainer that persecution trumped legality. ${ }^{99}$

In hindsight, even Lösener admits the irrelevance of legal rules and legal protections when it came to the so-called Jewish Question: "all [our] legal recommendations were disregarded" by the Party and the SS. ${ }^{100}$ Heydrich and Himmler ignored the Interior Ministry, and "their success was pre-programmed from the very beginning." ${ }^{101}$ One wants to ask: what took you so long to figure that out?

There are far worse sins than wishful thinking and self-deception, and far worse superstitions than faith in the law. Nothing I have said rebuts Lösener's claim that by staying on the job he saved lives. At this point, we must look more closely at what he did in his capacity as a lawyer.

\section{LÖSENER'S BATTLES}

We have already seen the first legal battle Lösener fought: to narrow the number of people the Nuremberg Laws would harm by restricting the persecutions to "full Jews." But the Party radicals did not relent, and so he had to wage a continuing campaign, "a tough battle to prevent the laws from changing - that is, worsening." ${ }^{102}$ Then Hitler verbally ordered that a paragraph Lösener had worked hard to include in the first implementing decree should not be enforced. ${ }^{103}$ In Lösener's official annotations, he gives no hint that the paragraph was now unenforceable, but as ministries queried him about what it all meant, "I was called upon to draft the most ridiculous oracular decisions and distribute convoluted information." 104

Lösener tried to get half-Jews exempted from the laws, and he estimates that this protected 100,000 people; he also succeeded in eliminating racial classification questions from the 1939 census. ${ }^{105}$ Lösener's next battle was to protect Jewish partners in mixed marriages. By this time "official hatred of Jews had reached a boiling point," and "my opponents in the Party and the SS were more vicious and dangerous to me personally than my opponents from the time of the Nuremberg Laws." ${ }^{106}$ In 1939 he succeeded in protecting some mixed-marriage families from confinement in ghettos, by arguing that it would be wrong to

99. Hitler countermanding Lösener. Jewish Desk, supra note 43, at 62; see infra text accompanying note 103.

100. Jewish Desk, supra note 43 , at 55.

101. Id. at 95 .

102. Id. at 56 .

103. 103. Id. at 62. Lösener's paragraph "annulled all the Aryan paragraphs that had so quickly permeated the bylaws and statutes of almost every private club in Germany and thus inflicted so much suffering on "nonAryans'."

104. $I d$.

105. Id. at 60 .

106. Id. at 63,66 . 
ghettoize the Aryan spouse and the half-Aryan children. ${ }^{107}$ His most important success, Lösener tells us, was talking Himmler into exempting Jews in mixed marriages from deportation to death camps, which in his estimate saved 20,000 lives. ${ }^{108}$

It was an uphill struggle. In the early days of the war, one of his efforts to protect Mischlinge failed. ${ }^{109}$ Then, after the mass murders of Jews began, Lösener drafted Stuckart's notorious proposal to have Mischlinge sterilized, which (as noted above) Lösener defended as a desperate compromise effort to save them from death. Next came a successful fight to exclude some Jewish members of mixed marriages from the order that Jews must wear a yellow star. ${ }^{110}$

These were bureaucratic battles at the policy level. In addition, Lösener tells us that he met continually with individual Jews seeking help and advice, which he tried to provide either by pointing out legal loopholes or-secretly-extra-legal possibilities. "Frequently I was sought out at home ... by the persecuted or their friends and agents, not to mention my own Jewish or half-Jewish friends and acquaintances with whom I never broke off personal relationships." He adds: "My official task in the Hitler State should have been to see to the strictest implementation of anti-Semitic legislation-in other words, to refuse help of any kind. With every act of assistance I was doing exactly the opposite of what was demanded by 'Party and State" ${ }^{\prime 11}$

\section{STAYING OR QUITTING}

Lösener's battles involved perpetual compromise, politically but also morally. He claims he was outspoken: "in the interests of the cause I never refrained from expressing my opinion very definitely" at conferences, so much so that "the expression 'friend of the Jews' was often to be heard and it could have been fatal at that time." ${ }^{112}$ The fact that for strategic reasons he offered only pragmatic arguments against persecution casts some doubt on this claim of outspokenness. For example, he argued in Nuremberg that broadening the definition to include Mischlinge might turn every German family where someone had a Jewish relative against the regime. Indeed, he walks back his claim of forthrightness:

[T] here were periods when we said, 'you can only go as far as this in your resistance. If you go any further, then you spoil the whole thing. Then you go too far. You break the camel's back. That was the well known border line to our resistance. But it was not fear of the Party which determined the limit-just objective considerations. ${ }^{113}$

\footnotetext{
107. Id. at 67 .

108. $I d$ at 68 .

109. Id. at 76

110. Id. at 95 .

111. Id. at 96 .

112. Schleunes, supra note 5, at 133 (including an English translation of the testimony).

113. Id.
} 
Stuckart, who was his ally, "admonished me not to insist too stubbornly on all of my goals in order not to jeopardize what we had already achieved. He was right." ${ }^{114}$ The sterilization memo Lösener drafted for Stuckart is the most graphic case of the kind of horrifying moral compromise to which Lösener refers. He could never "use the only real arguments of basic humanity, ethics, and above all religion, which for upright individuals would have been persuasive, because my opponents were not upright individuals."115

At one point, his adversaries tried to neutralize him by offering him a high Party job, which he declined "because I was clear in my mind about not wanting to sell my soul to the devil." "116 But wasn't he already working for the devil? Lösener squarely faced the dilemma of quitting and chose to stay. "Over and over again, my personal and political friends, as well as those seeking advice from among the ranks of the affected, persuaded me to remain in my position even as disgust threatened to choke me." 117 And not only other people-he hints at a sense of divine mission:

At times the ambiguity of my position, the condemnation to constant hypocrisy and webs of intrigue, the consciousness of being powerless to effect any real change, as well as the ever increasing threats of danger to my person turned life into true hell for me. Therefore, I must explain here why I held on to this vulnerable position: I arrived at this strange situation [as Jewish expert] ... by way of a series of most unlikely accidents .... I regarded this as providential, a commission from a higher authority to do that which I then proceeded to do. ${ }^{118}$

As we have seen, it was news of the 1941 massacre near Riga that drove him to quit, although Lösener does not suggest that he felt morally complicit with it in any way-only that his name was so prominently connected with the Jewish Question that he feared he would be associated with the Final Solution in the minds of others. He therefore asked not only for a transfer, but for the transfer to be publicized as widely as possible. ${ }^{119}$

Stuckart argued with him, pointing out that the murders were happening "on the highest orders." Lösener: "I pointed at my breast and replied that there was a judge here who told me what I had to do." "20 Stuckart granted his transfer, but berated him for his "cramped up" obsession with the Nuremberg Laws that

114. Jewish Desk, supra note 43 , at 59.

115. Id. at 40. See also Schleunes, supra note 5, at 140 (Lösener observing that "the real argument, namely, humane considerations, could not be mentioned because if anybody talked to Hitler about pity and human dignity, then the man who used the argument had lost from the beginning").

116. Jewish Desk, supra note 43, at 61.

117. Id. at 39 .

118. Id. at 95 .

119. Id. at 100 .

120. Id. at 100 . 
aroused anger and stopped them from accomplishing more. For all his compromises, apparently Lösener did not compromise enough.

Lösener does not seem to be a man of great introspection. He says nothing more about the judge within him-nor what the judge within had to say as he "continued to conduct the most pressing official business" during the months he was awaiting his transfer. Was the judge an inner voice of conscience? Was it a divine voice? Remember that "the only real arguments" against persecutions were "basic humanity, ethics, and above all religion." 121 We don't know; and perhaps he did not know. When he speaks of his providential mission as a commission from a higher authority, he sounds like a bureaucrat in the Interior Ministry of Heaven.

\section{SPIELRAUM In THE INTERIOR MinisTRY}

Lösener emphasizes the danger he was in as a result of being labeled a "friend of the Jews," a label delivered "always with the undertone of an already palpable threat." 122 He adds: "More than once I burned letters and other correspondence in my apartment because of the constantly growing mistrust of the Party and the possibility they would search my home." 123 These threats, though, came from outside the Ministry. Within the Ministry, matters were different. He tells us Stuckart was his ally. His first boss, Pfundtner, also rejected the persecution of Jews "deep inside himself"; his other superiors were "old competent bureaucrats." ${ }^{24}$ And "[f]ortunately, the Ministry of the Interior also had quite a few staff members who fought against the Party with every means at their disposal, and continued to do so until the very end." 125 Several times Lösener tells us that he was not operating alone. ${ }^{126}$ But their scope for accomplishment was pitifully narrow. The jurisdiction of the Interior Ministry was Germany, not the East-and so the German Jews were the only Jews they could try to succor. They had no control over the SS; and Frick, the Interior Minister, was disengaged and gave them no support—but also no opposition. ${ }^{127}$ So Lösener's Spielraum was at once wide and narrow-wide internally, because he had allies in the office to protect and support his efforts (and perhaps keep his moral judgment on track) but narrow externally, because he was waging a war of legalism to protect sub-categories of Jews, against adversaries with more power who had only contempt for law and lawyers.

121. Id. at 40 (emphasis added).

122. Id. at 101 .

123. Id.

124. Id. at 37

125. Id. at 38 .

126. Id. at 44; Schleunes, supra note 5, at 118.

127. The Allies tried Frick at Nuremberg for crimes against peace, war crimes, and crimes against humanity. He was convicted and executed in 1946. 
How should we evaluate the enigmatic Lösener? I defer that discussion until we have our second case study before us.

\section{Von MoltKe And The ABWEHR}

Far better known than Lösener is Count Helmuth James von Moltke, another lawyer in the proverbial belly of the beast, and one of the martyrs of the clandestine opposition. Moltke, born in 1907, bore one of Germany's most celebrated names: his great-uncle and great-great-uncle had both been the Army Chiefs of Staff, the former in World War I and the latter in Bismarck's Prussia. Both field marshals were also called Helmuth, and the illustrious name probably protected the youngest Helmuth well past the time he might otherwise have perished.

Moltke's legal specialty was international business law, which he practiced in a small Berlin firm before the war; in the 1930s, much of the firm's practice was dedicated to helping Jews and others flee from Germany. ${ }^{128}$ International law "gives one the feeling of doing something really important for the world and for Europe especially." ${ }^{29}$ Business was good, ironically, because the international law bar was heavily Jewish, and the expulsion of Jews from the legal profession opened up more opportunities. ${ }^{130}$

From the beginning of the Third Reich, there were anti-Nazi aristocrats in Germany. When the Gestapo finally got wise to the Widerstand, the internal opposition circles, they nicknamed one of them the Grafengruppe, the "group of Counts" (Graffengruppe). ${ }^{131}$ Most were conservatives who viewed Hitler and his followers with the contempt of the nobility toward the masses but who also were no friends of the Weimar Republic. ${ }^{132}$ Among these were monarchists who had never abandoned their loyalty to the Kaiser. Other aristocratic opponents came from the military; these were men who loathed Hitler and held the double conviction that not only would Hitler's war destroy Germany but also that Hitler was tarnishing military honor with atrocity. The various resistance circles did not always like or trust each other. Claus von Stauffenberg, the leader of the failed bomb plot to kill Hitler, said after his first meeting with Moltke that he "cannot stand this man, this Helmuth Moltke."133

128. BALFOUR \& FRISBY, supra note 48 , at 74.

129. Letter (in English) from Moltke to his grandmother (Dec. 10, 1934), in GRAF VON MOLTKE supra note 49 , at 105 .

130. BALFOUR \& FRISBY, supra note 48 , at 65.

131. Id. at 111. Balfour and Frisby think that "opposition" is an inapt translation of Widerstand, because it suggests open parliamentary opposition. They also reject "resistance," which calls up images of an underground guerrilla movement. The German Widerstand was neither. Id. at 97.

132. See Hans Mommsen, Alternatives to Hitler: German Resistance to the Third Reich $23-49$ (Angus McGeoch trans., 2003).

133. KARLAUF, supra note 20, at 267. The same with Carl Friedrich Goerdeler, another conservative resistance leader, to whose circle Lösener claimed to belong: relations between Moltke's circle and Goerdeler's "ranged from icy to aggressive," largely because Goerdeler's was far more nationalist than the Kreisau Circle. Id. at 268. The Stauffenberg group's July 20, 1944 plot to kill Hitler is the best known of several failed 
To understand Moltke, it is crucial to know that aristocratic conservatism was not his outlook-far from it.

As an idealistic young man, he became involved in progressive education projects for workers. In his farewell letter to his wife on the eve of his execution, he mentions his "socialist leanings;", 134 decades earlier, on the occasion of having to cut workers' wages on the family estate because of impending bankruptcy caused by his father's mismanagement, he had written her that "it is thoroughly unpleasant to have to carry out the capitalist system against one's convictions." 135 On the other hand, in 1934 he wrote to a friend that he is "above having socialist inclinations." $" 136$

Whatever his economic views may have been, Moltke's outlook was never nationalist. At age twenty-one he wrote: "I feel I am bound firstly to Europe, secondly to Germany, thirdly to East-Germany" - his home region-and "fourthly to the land." He added, "I 'feel bound' means, that I feel responsible, the degree of the responsibility weakening with the widening of the circle." 137 By "the land," he meant "the agricultural, european [sic] east"-the Silesian locale of his beloved family estate in Kreisau (today Krzyzowa, Poland)-for which "the intensity of feeling of responsibility is overwhelming." Responsibility for "Germany's questions" comes only third in his priorities. ${ }^{138}$

That Europe is on his list of responsibilities likewise shows an anti-nationalist outlook. During the war, Moltke secretly assembled a clandestine group of antiNazis, known today as the Kreisau Circle, to plan a post-Hitler German reconstruction. The planning documents envisioned a European Federation to which Germany would belong, and the U.S. diplomat George Kennan recalls his astonishment when he met Moltke in Berlin in 1940 and found him studying The Federalist Papers:

[T] he picture of this scion of a famous Prussian military family, himself employed by the German general staff in the midst of a great world war, hiding himself away and turning, in all humility, to the works of some of the founding fathers of our own democracy for ideas as to how Germany might be led out of its existing corruption and bewilderment has never left me. ${ }^{139}$

assassination attempts, and it was the subject of the 2008 film Valkyrie, with Tom Cruise cast as Stauffenberg. The bomb Stauffenberg smuggled into a meeting with Hitler detonated, but Hitler suffered only minor injuries.

134. LETTERS TO FREYA, supra note 47, at 410 (letter sent the eve of his execution, Jan. 11, 1945).

135. BALFOUR \& FrISBY, supra note 48, at 44. Deichmann was Freya von Moltke's birth name.

136. GRAF VON MOLTKE, supra note 49 , at 84.

137. Id., supra note 49, at 54-55 (including a letter (in English) to his grandfather on November 12 and 25 , 1928).

138. Id. at 55. Moltke biographer Günter Brakelmann confirms that by his early 20 s Moltke already believed that the nation-state principle was no longer viable in Europe and must be replaced by a united Europe. Helmuth James Von Moltke, 1907-1945: Eine Biographie 54 (2007). Moltke published an essay on this point in 1928 in an American magazine. $I d$. at 57.

139. George F. Kennan, Memoirs 1921-1950 121 (1967). 
The political program of the Kreisau Circle disfavored strong central government and hoped for local control and revitalized churches and labor unions. As I discuss later, Moltke, like many of the other Kreisauers, held Christian convictions that grew more profound as the war went on.

Moltke was of English descent on his mother's side-his grandfather was Chief Justice of South Africa-and he had strong English connections. After law school and a nerve-wracking year at home rescuing Kreisau from bankruptcy, ${ }^{140}$ he studied at London's Inner Temple and qualified as a British barrister. He made close English friends. As war approached he considered emigrating to England, where-though his professional prospects were dim-he would have a chance at "defending and perhaps restating the European creed versus the Caesarian creed." 141 It was tempting to leave Germany, because "it is torturing me because in my profession one cannot help aiding those whose spirit is governing this country." ${ }^{142}$ (Obedience is support!) As he explained to his grandfather, international business law had now deteriorated into bribing and networking with ministry officials: "derogatory of one's mind and one's conscience."143 But he did not emigrate.

Many Germans practiced "inner emigration"- - withdrawal into private life and emotional disaffiliation with the Third Reich. ${ }^{144}$ More than once Moltke wrote wistfully to his wife about life in Kreisau; but he was temperamentally unsuited for inner emigration. ${ }^{145}$ To a British friend, he explained: "I can return to Kreisau and live there the life of a tiller of the soil with all the amenities and drawbacks of country life and with the absolute certainty, that never in my life will I be able to do anything useful, i.e., anything assisting those to whom I really belong."

Instead, he entered government service at the peak of Nazi power, shortly before the war. And that makes him a man of paradox. In 1939 Moltke joined the international law department of the Abwehr, the intelligence service of the military high command (the Oberkommando der Wehrmacht or OKW). His job as a

140. BALFOUR \& FRISBY, supra note 48 , at $38-45$.

141. GRAF VON MOLTKE, supra note 49, at 101 (including a letter from Moltke to Lionel Curtis in English on Feb. 15, 1939).

142. Id.

143. GRAF VON MOLTKE, supra note 49, at 119-120 (including a letter from Moltke to his grandfather in English on June 25, 1939). He added, "this is the result of a system of government which has placed into the hands of officials of every grade the power to give decisions ... on grounds of expediency, uncontrolled and uncontrollable by any impartial person, open to influences of various and dubious kinds. ... No person with self respect [sic] could agree to act under such conditions unless he is forced to do so under the stress of making a living coute que coute." $I d$. at 120 .

144. On the concept of "inner emigration," see supra note 19.

145. GRAF VON MOLTKE, supra note 49, at 69 (including letters from Moltke to Freya on May 21, 1940, Aug. 4, 1940, Dec. 10, 1941, Sept. 14, 1942, and July 17, 1943). See also the passages in Balfour and Frisby's biography indexed under "Kreisau Estate with Nieder Gräditz and Wierischau, Helmuth's devotion to and longing for." BALFOUR \& FRISBY, supra note 48 , at 384.

146. Graf von MOLTKe, supra note 49, at 101 (including a letter from Moltke to Curtis on Feb. 15, 1939). For an analysis of the options facing anti-Nazis, see BALFOUR \& FRISBY, supra note 48, at 60-63. 
civilian adviser on international law was liaising between the OKW and the Foreign Office; his official title was War Administrative Counselor to the Foreign Countries Division of the Abwehr. ${ }^{147}$

Military intelligence seems like an improbable home for an anti-Nazi. But, surprisingly, the Abwehr turned out to be a center of underground resistance among German officialdom. At the Nuremberg trial of major war criminals, the head of the OKW called the Abwehr a "nest of conspirators" - an exaggeration with a grain of truth - and today's right-wing conspiracists would call it the Deep State. Its chief, Admiral Wilhelm Canaris, was executed for high treason in 1945 after Gestapo investigators discovered his diaries. ${ }^{148}$ At Himmler's urging, Hitler abolished the Abwehr in 1944. But until 1944, the Abwehr provided Moltke a measure of protection and unusual Spielraum.

The Abwehr was locked in perpetual competition with the infamous, Partydominated Head Office of Security (Reichsicherheitshausamt or RSHA), home of the SD and the Gestapo. The Abwehr's military perch gave it leverage, for of course military intelligence was vital. Abwehr members were also partially shielded from investigation, because the Abwehr rather than the RSHA kept their dossiers. Nest of conspirators or not, Moltke had no reason to doubt that the Abwehr would contribute to the war effort ${ }^{149}$ hence the moral ambiguity of working there. Although he was convinced from the beginning that Germany would lose the war, Moltke was not rooting for the enemy: in a 1941 letter to his wife, he described reports that the Red Army was weaker than the Germans feared as "excellent news." 150 In the final years of the war, however, that changed: it was clear that the war was lost, and the sooner it ended the better. He tried to make secret contact with the Allies. In fact, Moltke's memorandum made it to the desk of President Roosevelt, but Supreme Court Justice Felix Frankfurter mistakenly advised F.D.R. "that it was a decoy by people who were not sincere."151

147. BALFOUR \& FRISBY, supra note 48 , at 94.

148. Canaris is a celebrated hero of the Widerstand. See RICHARD BASSETT, HitLER's SPy CHIEF (2011).

149. In fact, there is reason to believe that Canaris deliberately sabotaged the war effort, most dramatically by secretly undermining a Hitler-Franco alliance to capture Gibraltar, and by overestimating British strength at Dunkirk in his intelligence reports, leading Hitler to delay the attack on beleaguered British forces long enough for the famous evacuation. Id. at 296. But Moltke was almost certainly in no position to know what Canaris was up to-such secret machinations were taking place above his pay grade. All Moltke was in a position to know is that Canaris had a commitment to ethical standards that "permeated everything the Abwehr undertook." Id. at 297.

150. LetTERS TO FreyA, supra note 47, at 168 (including a letter from Moltke to Freya on Oct. 9, 1941).

151. BALFOUR \& FrISBY, supra note 48, at 277. See Memorandum from Count Helmuth James von Moltke to Hans Wilbrandt and Alexander Rüstow on Conditions in Germany and the Warsaw Ghetto Uprising (July 9 , 1943) (German History Documents and Images) http://germanhistorydocs.ghi-dc.org/sub_document.cfm? document_id=1517 [https://perma.cc/WVB7-JCYM] (last visited Apr. 7, 2021). Balfour and Frisby assert that Frankfurter gave the same skeptical advice to F.D.R. about information from one of Moltke's Kreisau Circle associates, Adam von Trott, but Frankfurter denies the latter. Letter from Felix Frankfurter, Justice, Supreme Court, to Arthur Schlesinger (June 11, 1951). Hans Rothfels, the source of the Frankfurter/F.D.R./von Trott story, contradicts Frankfurter. Letter from Hans Rothfels to Arthur Schlesinger (June 26, 1951). I am grateful to Brad Snyder for providing me these two letters. 
Today, what we remember Moltke for is his clandestine organizing of the Kreisau Circle. Its aim: to plan a future, post-Hitler Germany after the war. He was convinced that the churches and labor unions would be central institutions in the new state; arguably, the postwar rise of the Christian Democrats and Social Democrats prove that Moltke was prescient. ${ }^{152}$ Most of the Kreisau Circle's planning focused on these two institutions, which seemed like the easiest to approach and recruit. ${ }^{153}$ Meetings were conducted in utmost secrecy and Moltke's letters to Freya are filled with a brutally exhausting catalogue of luncheons, dinners, and conversations far into the night as he cautiously felt out potential recruits and traded ideas.

From the beginning, some members of the Kreisau Circle hoped (in vain) for a military coup, and a few thought assassinating Hitler would be a necessary first step. ${ }^{154}$ Moltke himself eventually agreed that a coup was essential, but he drew the line at assassination. "Why are we opposed to the Third Reich and to National Socialism? Surely because it is a criminal system and one ought not to begin something new with a new crime. Murder is always a crime." 155 To one resistance member, he said, "Let him live. He and his party must shoulder right to the end the responsibility for the terrible fate which they have brought on the German people. This is the only way to eradicate the ideology of National Socialism." 156 Moltke was not involved in the July 20th plot—by then he was already in custody for having warned someone not to speak openly to a provocateur. ${ }^{157}$ But the wide-ranging Gestapo investigation of the plot also unwound other opposition circles, revealed Moltke's resistance activities, and ultimately led to his trial and execution.

But Moltke's extracurricular resistance work is not the focus here. My questions are about what Moltke did on the job-his legal work. Did he actually make a difference, or was he deluding himself with lesser-evilism? Did he keep his principles intact, or become inured and indifferent? Did he help or hinder the German war effort? ${ }^{158}$ Above all: did he commit a moral error by working in the Abwehr?

152. Among the founders of the Berlin CDU was one member of the Kreisau Circle. BALFOUR \& FrISBY, supra note 48, at 244. For a detailed account of the Kreisau Circle's program, including relevant correspondence and documents, see Ger van Roon, German Resistance to Hitler: Count von Moltke and The KREISAU CIRCLE (Peter Ludlow trans., 1971); BALFOUR \& FRISBY, supra note 48, 237-57.

153. BALFOUR \& FRISBY, supra note 48 , at 180-98, 207.

154. Id. at $209-10$.

155. Id. at 210 . They attribute this view to Moltke's Christian convictions.

156. Id. at 263. However, General Falkenhausen, to whom Moltke said this, also recalls him saying, "In spite of all doubts we have no other choice open to us except to eliminate Hitler physically." Id. at 264.

157. Freya von Moltke explains the circumstances in an account of Moltke's imprisonment that she wrote in 1989. MEMORIES OF KREISAU, supra note 47, at 385.

158. Of course, he might have done both, at different times. For example, Admiral Canaris, head of the Abwehr, maintained lines of communication with his British counterparts, and thought the Abwehr could help with backchannel peace-making. Eventually he concluded that nothing short of Germany's defeat could save the country, and, as his biographer notes, "Canaris had now stepped irrevocably beyond the frontiers of seeking 
There is no doubt that he never drifted into the "Complacent State." He well understood the catastrophic collapse of personal judgment that so preoccupies Arendt. He writes to Freya: "I am constantly surprised at the extent to which all these people have lost their orientation. It is just like a game of blind man's bluff: they have been turned round and round blindfolded and no longer know what is left and right, front and back." ${ }^{59}$ The pliant adaptability of fellow officials infuriated him.

I am so bitter, not to say ready to explode.... These people have a restricted horizon, they do not see that every action takes its place in the universe, that all things are interrelated, that a murder in Warsaw has repercussions in Calcutta and Sydney, at the North Pole, and in Kurdistan, not political but moral repercussions... Take this example: yesterday I was at a meeting in the Foreign Ministry about the persecution of the Jews. It was my first official contact with this question. Against 24 men, and quite inflexibly I attacked a decree which already had the approval of all ministers and the Chief of the OKW, and for the moment have halted its course. And when I returned, the OKW official in whose competence it really fell asked me: Why did you do it? You can't change things, although of course these measures are catastrophic.... I quite appreciate the charm and the qualities of these men, but their actions are dictated by expediency and have no moral basis. They are like chameleons: in a healthy society they look healthy, in a sick one, like ours, they look sick. And they are neither one nor the other. They are mere filler (Füllsel). ${ }^{160}$

The decree in question, coincidentally, was one of the implementing decrees of the Nuremberg Laws-the handiwork of Lösener's ministry. ${ }^{161}$

And the question of complicity haunted Moltke. In October of 1941, he wrote to Freya:

The day is so full of gruesome news that I cannot write in peace .... What affects me most at the moment is the inadequacy of the reactions in the military. Falkenhausen and Stuilpnagel [German commanders in France] have returned to their posts instead of resigning after the latest incidents [of hostage-murders], dreadful new orders are being issued, and nobody seems to see anything wrong in it all. How is one to bear the burden of complicity?

\footnotetext{
an understanding with the enemy to actively helping him." BASSETT, supra note 148 , at 277 . It seems likely that Moltke did the same.

159. Letters to FreYA, supra note 47, at 113 (including a letter from Moltke to Freya on Sept. 10, 1940).

160. Id at $179-180$.

161. 11th Decree under the Reich Citizenship Law, Nov. 25, 1941, rendering German Jews abroad stateless (including Jews who were deported). There was also an unpublished Interior Ministry regulation that applied the 11th Decree to the General Government, Ostland, and Ukraine. It did not call it "deportation," but pretended theirs was voluntary emigration. LETTERS TO FREYA, supra note 47, at $180 \mathrm{n} .1$.
} 


\section{After describing atrocities in Serbia and France, Moltke continues:}

And all this is child's play compared with what is happening in Poland and Russia. May I know this and yet sit at my table in my heated flat and have tea? Don't I thereby become guilty too? What shall I say when I am asked: and what did you do during that time?

Since Saturday the Berlin Jews are being rounded up [for deportation to ghettos in Łodz and Smolensk]. . . . How can anyone know these things and still walk around free? With what right? ... - If only I could get rid of the terrible feeling that I have let myself be corrupted, that I do not react keenly enough to such things, that they torment me without producing a spontaneous reaction. I have mistrained myself, for in such things, too, I react with my head. I think about a possible reaction instead of acting. ${ }^{162}$

Notice that in this letter he is not worried specifically that his service in the Abwehr makes him complicit in evil. His worry is that anything other than direct resistance, in whatever form, makes him complicit in evil. To him, sitting in his flat drinking tea makes him complicit.

This is the kind of guilt that the philosopher Karl Jaspers labeled "metaphysical" and defined as the guilt of going about one's daily life in knowing proximity to evil, and yet doing nothing. ${ }^{163}$ Jaspers dubbed it "metaphysical" rather than moral because he did not think anyone is morally obligated to throw their life away in ineffectual protests. Living under the shadow of Gestapo terror, there is no moral guilt in doing nothing; nor, obviously, is there criminal guilt. ${ }^{164}$ But, in Jaspers's view, there is guilt all the same, and what makes it "metaphysical" is that it is guilt at betraying human solidarity.

On the other hand, Moltke clearly believed that the guilt of anti-Nazis in the military who did nothing is not merely metaphysical. He writes bitterly to Freya

162. LeTtERS TO FREYA, supra note 47, at 174-175 (including a letter from Moltke to Freya on Oct. 21, 1941).

163. KaRL JASPERS, The Question OF GeRMAn GuLt (1947). This remarkable book grew out of a lecture Jaspers gave at the reopening of the University of Heidelberg in 1945-a reopening that "German students applauded by pounding their desks." New Heidelberg, STARS \& STRIPES (Aug. 26, 1945). It was the first open discussion of German guilt by any public figure in Germany. Jaspers had been fired from the university in 1937 on account of his Jewish wife. Stars and Stripes artist Al Lichtenberg, interviewing students at the lecture, found that "for the most part" they rejected Hitler's "race hygiene," although one student replied, "Don't you in the U.S.A. believe in the superiority of the white race?" Id. (I note for the record that Al Lichtenberg, the Stars and Stripes interviewer, now deceased, is my father-in-law.).

164. This is a debatable proposition. See Amos Guiora, The CRIME of Complicity: The Bystander IN THE HOLOCAUST (2017). Reflecting on bystanders to the Holocaust who could have done something to save lives but did not, Guiora proposes a legally enforceable duty to rescue. Id. at 4 . That is because he regards failure to act as complicity in the harm that befalls victims. $I d$. at 7 . He does not, however, consider cases like Lösener's or Moltke's, where remaining in a job that enables them to rescue may simultaneously be a form of complicity. For a contrary view to Guiora's, see Amelia J. Uelmen, The Kindness of Strangers and the Limits of the Law: The Moral and Legal Obligations of Bystanders to a Vulnerable Person in Need of Emergency Assistance (2015) (S.J.D. Thesis, Georgetown University Law Center) and Amelia J. Uelmen, Crime Spectators and the Tort of Objectification, 12 U. MASS. L. REV. 68 (2017). 
about his uncle Carl's mind-your-own-business attitude, serving as a Wehrmacht officer:

No doubt it is more comfortable to feel responsible for a few people only and deliberately wear blinkers that prevent one from seeing the evil done in the discharge of this responsibility - to be unwilling to see that one is defending murder and robbery. In reality it is these people who are the crux of the evil, not the criminals. There are and have been criminals everywhere; but it is the inescapable duty of all the righteous to keep crime within bounds, and whoever evades this task is more guilty than the criminal himself. ${ }^{165}$

In an obvious way, this view comes close to Arendt's "obedience is support." But it sharply breaks with her on the issue of lesser-evilism: "it is the inescapable duty of all the righteous to keep crime within bounds" not only permits seeking the lesser evil but morally requires it.

Probably for that reason, Moltke never resigned, unlike Lösener. It seems clear that he thought he was in a better position inside the Abwehr than he could be outside to discharge "the inescapable duty of all the righteous to keep crime within bounds." Among other advantages, working in military intelligence gave him access to reports of what was actually going on in the war, rather than the censored news and lies from the Ministry of Propaganda. ${ }^{166}$

In August 1941, Moltke reported to Freya that Jews were being massacred in the East. ${ }^{167}$ Moltke added that eventually the nation would learn that it bears "a blood-guilt that cannot be atoned for in our lifetime and can never be forgotten." ${ }^{168}$ He learned about gas chambers in 1942 from his brother-in-law who had visited Auschwitz, and in October he wrote an understated, almost affectless letter to Freya:

Yesterday's lunch was interesting in that the man I ate with had just come from the Government [in Poland] and gave an authentic report on the "SS blast furnace." So far I had not believed it, but he assured me that it was true: 6000 people a day are "processed" in this furnace. He was in a prison camp $6 \mathrm{~km}$

165. LetTers to FreyA, supra note 47, at 178 (including a letter from Moltke to Freya on Nov. 6, 1941).

166. Balfour and Frisby suggest that Moltke's unit was "one of the few places in the whole German machine where a clear view could be had of the war as a whole." BALFOUR \& FRISBY, supra note 48, at 95.

167. LeTters to FREYA, supra note 47, at 155-156 (including a letter from Moltke to Freya on Aug. 26, 1941). Göring had commissioned the "Final Solution of the Jewish question" a month earlier. Letter from Göring to Heydrich (July 31, 1941), https://www.ghwk.de/fileadmin/user_upload/pdf-wannsee/engl/goering. pdf [https://perma.cc/AM6B-6BP5]. Moltke obviously knew nothing about this top-secret order, nor did he know about the Wannsee conference in January 1942, where the Final Solution was briefed to the ministries. The Abwehr was not invited to the Wannsee conference. Although the Final Solution directive is from Göring to Heydrich, historians believe that Heydrich pressed Göring to issue it; and presumably it originated with Hitler, although Hitler never put the order in writing.

168. LetTers to FreyA, supra note 47, at 155-156 (including a letter from Moltke to Freya on Aug. 26, 1941). 
away, and the officers there reported it to him as absolute fact. They also told some quite fantastic stories about some of the gentlemen employed there. ${ }^{169}$

Still he did not resign. One telling letter, in which he describes unbearable incidents, explains why:

Russian prisoners, evacuated Jews, evacuated Jews, Russian prisoners, hostages shot, gradual encroachment in the Reich itself of measures "tried and proved" in occupied territories, again evacuated Jews, Russian prisoners, a Mental Home for SS men who broke down "executing" women and children. That was the world of these two days. Yesterday I said goodbye to a once famous Jewish lawyer ... who will kill himself with his wife today because he is to be picked up tonight. ... And yet I was actually able to throw a spanner in the works, obstructing a bit, at least, of the persecution of the Jews. ... Which proves the general rule that as soon as one man takes a stand, a surprising number of others will stand, too. But there always has to be one to go first; otherwise it does not work. ${ }^{170}$

\section{MOLTKE's LEGAL WORK}

The bulk of Moltke's legal work in the Abwehr consisted of ceaseless efforts to get the German military to comply with international law. The issues were varied. ${ }^{171}$ In the early days of the war, he was concerned with economic warfare and seizure of enemy property. A few letters from the early months of the war:

October 18, 1939: "I'm to give a talk on the seizure of enemy property to people in the various ministries concerned. ... That basically pleases me; it gives me a chance to prevent some nonsense." 172

November 25, 1939: "Yesterday I didn't write. From early in the day till late at night I fought a war measure [on economic warfare] in a minority of 1:25. It was a brutal strain, particularly since the others continually used against me a Fuihrer Order, which is already out. So the decision yesterday went against me. This morning I took the matter to my chief and got his complete backing; with this backing I resumed the fight this morning." 173

Two days later: "Today I won my case. But it was like winning a victory over a hydra. I chopped off one of the monster's heads, and 10 new ones have grown in its place." ${ }^{174}$

169. Id. at 252. The "Government" to which Moltke refers is the Nazi occupation government in Poland, referred to officially as the "Generalgouvernement," that is, General Government.

170. Id. at 185. "Evacuated" was the SS euphemism for those sent to the death camps.

171. For an overview of Moltke's wartime legal work, see the short memoir by his $A b w e h r$ legal colleague and comrade-in-arms. Wilhelm Wengler: Wengler, Errinerungen, in GRAF VON MOLTKE, supra note 49, at $319-327$.

172. LetTers to Freya, supra note 47, at 40 (including a letter from Moltke to Freya on Oct. 18, 1939).

173. Id. at 47 (including a letter from Moltke to Freya on Nov. 25, 1939).

174. $I d$. 
Moltke reflected with satisfaction on his autumn accomplishments in a letter of December 17th, 1939: "I find that I've never before prevented so much evil and achieved so much good. It astounds me."175

Later, more lethal issues occupied him, such as the shooting of prisoners.

March 7, 1940. "Once more I was defeated in the large group, deserted by Bürkner [his sympathetic boss] this time, on a question which in my view will have quite a decisive influence on the German position in the post-war world. ... But I remained unconvinced and asked permission to exercise the right of every official to have his dissenting opinion put on record. ... The matter came before the admiral [Schuster], and after 5 minutes he endorsed my opinion. ... Result: the admiral will represent the opinion of the sections officially but will have his personal dissent recorded in the minutes and will also speak to these minutes before the Fuihrer." 176

The next day: "Today I celebrated a great triumph. ... At 6.30 came a Führer Order with my conclusion and with my arguments. ... A great disaster has been averted, and despite everything it gives me great satisfaction to think that many non-German women have your husband to thank for the continued existence of theirs." 177

In June 1940 the issue was the rights of Poles in occupied areas. ${ }^{178}$ In July it was forced labor ("the slave trade"); in September, whether the economic life of occupied territories should be maintained or dismantled. ${ }^{179}$ In April 1941 Moltke headed off an order to have the Gestapo assassinate the British ambassador to Switzerland. ${ }^{180}$ Later that year he wrote a memo insisting that it is illegal to take revenge on POWs (but General Keitel brushed it off). ${ }^{181}$ But in September, Moltke was successful in stopping a plan to transport 500 Jewish hostages to their deaths as payback for every dead German soldier. ${ }^{182}$ Then, in 1942, Hitler ordered that captured commandos be shot. ${ }^{183}$ Moltke writes to Freya:

Yesterday evening I had a decisive exchange with Bürkner. He didn't want to sign something that meant a great deal to me and argued with me about the justification of an undiluted murder Order by the Führer. I thereupon said to him:

175. Id. at 49 (including a letter from Moltke to Freya on Dec. 17, 1939).

176. Id. at 60 (including a letter from Moltke to Freya on Mar. 7, 1940).

177. Id. at 61 (including a letter from Moltke to Freya on Mar. 8, 1940). Balfour and Frisby believe the (unspecified) issue concerned shooting French prisoners. BALFOUR \& FRISBY, supra note 43, at n. $116, \mathbf{n} .117$.

178. LETTERS TO FREYA, supra note 47, at 77 (including a letter from Moltke to Freya on June 27, 1940 ).

179. Id. AT 79 (including a letter from Moltke to Freya on July 2, 1940); BALFOUR \& FrISBY, supra note 48 , at 134 (economic rights under occupation).

180. BALFOUR \& FRISBY, supra note 48 , at 148

181. Id. at 170 .

182. $I d$. at 171 .

183. Hitler issued the so-called "Commando Order" on October 18, 1942. See Typescript translation of the 'Führer Befehl', Hitler's 'Commando Order', 18 October 1942, NAT'L WAR MUSEUM, https://collection.nam. ac.uk/detail.php?acc=1992-03-218-111 [https://perma.cc/WN4T-2WD7] (last visited Apr. 9, 2021) (ordered summary execution of captured commandos, whether in or out of uniform). 
You see, Herr Admiral, the difference between us is that I can't argue about such questions. As long as I recognize imperatives that cannot be repealed by any Führer Order and that must be followed against a Führer Order, I cannot let such things pass, because for me the difference between good and evil, justice and injustice exists a priori. It is not subject to considerations of expediency or argument.-Whereupon he signed without demur. It is interesting to see again how such people can be swayed to the right side by a resolute stand. ${ }^{184}$

Resolute stand or not, Moltke and Bürkner failed, and the Commando Order stood. His friend and colleague Wengler comments on Moltke's frequent failures: "All the more admirable is the untiring patience with which he strove to contribute within the narrow confines of the humanization of war."

In the final months of 1943, his efforts involved travel to occupied Western countries to urge military commanders that they must not shoot hostages and prisoners. These visits were sometimes dual-purpose, allowing him to pass information to the Allies-where, as noted above, it was not trusted. ${ }^{186}$

All the while, Moltke was involved in individual cases; he rescued Jews and saved captured officers from execution when he could. Some of his victories were small, as in his effort to delay the conscription of Dutch, French, and Belgian civilians into forced labor. "I have saved 10 days of their lives for many hundreds of thousands of people, that is, days of their normal lives. That sort of thing still cheers one up." 187

But it was a cheerless cheer; Moltke complained to Wengler, "Anyone who wants to see his proposals translated into reality had better not come to work with us." 188

\section{MOLTKE'S SPIELRAUM}

Undoubtedly, Moltke had extraordinary Spielraum. Protected by a legendary military name and a title of nobility, insulated by his agency from Gestapo snooping, working in a center of resistance under a like-minded commander, being able to travel outside Germany, having access to accurate and up-to-date intelligencethese conditions put him in a position few other officials enjoyed in the Third Reich, or any other government for that matter. Perhaps, then, Moltke's situation was too atypical for us to draw any general conclusions about the power of officials to resist.

184. LeTters to FREYA, supra note 47, at 258 (including a letter from Moltke to Freya on Nov. 3, 1942). The editor of Letters to Freya believes this letter "almost certainly" refers to the Commando Order. Id. at 258 n.1.

185. Wengler, Errinerungen, supra note 171 , at 325 .

186. BALFOUR \& FRISBY, supra note 48 , at $258-81$.

187. LetTERS TO FREYA, supra note 47, at 297-298 (including a letter from Moltke to Freya on Apr. 16, 1943).

188. Wengler, Errinerungen, supra note 171, at 325. 
Yet this favorable alignment of stars doesn't tell the whole story. What comes through his reports is how much Moltke created his own Spielraum. He was outvoted twenty-five to one on economic warfare, and twenty-four to one on the persecution of Jews; and he was the only objector to the Commando Order. But he swayed his superiors on all of these.

These episodes show, first of all, that his colleagues were mostly not part of the resistance or a nest of conspirators; the Abwehr was working in the larger organization of the OKW and the Foreign Office. So the Spielraum he enjoyed was not as broad as it might appear at first glance.

Second, even those who shared his views didn't speak up. Recall Moltke's bitterness at the "chameleons," the men he called "mere filler." 189 These belong to what I earlier called the "complacent state," a phrase borrowed from former U.S. Foreign Service officer Chuck Park to explain why he resigned in protest. ${ }^{190}$ Moltke spoke up; indeed, he won over Admiral Schuster on the hostages issue, and he shamed Bürkner into endorsing his stand on the Commando Order. Lösener too says that he never refrained from expressing his opinion, but he also makes clear how circumspect and self-censoring he was. Moltke seems far more direct: he was willing to flatly dispute Führer Orders, which under Nazi legal doctrine had the force of law. ${ }^{191}$

That is important. Just as our judgment can be affected by complacent chameleons, outspoken opposition can sometimes affect them. Reciprocity reigns. Remember Moltke's earlier-quoted observations:

"It is interesting to see again how such people can be swayed to the right side by a resolute stand." 192

"Which proves the general rule that as soon as one man takes a stand, a surprising number of others will stand, too. But there always has to be one to go first; otherwise it does not work." ${ }^{193}$

The "minority influence" literature in experimental social psychology, pioneered by Serge Moscovici in the 1970s and 1980s, backs up these insights, especially in small groups. ${ }^{194}$ Plausibly, minority influence will be specially potent when members of the majority may secretly harbor minority opinions, or are only weakly committed to the majority opinion they endorsed. Granted that in the incidents Moltke reported, this did not happen: he lost unanimously in the group of twenty-four or twenty-five, but then went over their heads - to an even smaller

189. LetTers to FreyA, supra note 47, at 180 (including a letter from Moltke to Freya on Nov. 8,1941 ).

190. Park, supra note 8.

191. Arendt notices Eichmann's frequent use of the phrase Führerworte haben Gesetzeskraft, "The Führer's words have the force of law." ARENDT, EICHMANN IN JERUSALEM, supra note 2, at 148.

192. LeTTERS TO FREYA, supra note 47, at 258 (including a letter from Moltke to Freya on Nov. 3, 1942).

193. Id. at 185 (including a letter from Moltke to Freya on Nov. 13, 1941).

194. See, e.g., S. Moscovici, E. Lage \& M. Naffrechoux, Influence of a Consistent Minority on the Responses of a Majority in a Color Perception Task, 32 SOCIOMETRY 365 (1969). 
group. Presumably, his victories drew some resentment from the chameleons who voted against him-but the victories may also have carved out space for his work (he has the ear of the boss) and lent weight to his arguments and his moral authority. Spielraum is made, not just found.

\section{MOLTKE's CONSCIENCE}

Unlike Lösener, legalism does not seem to figure in Moltke's conscience. Of course, his advocacy efforts must have relied on legal arguments given that he was the international law specialist. But strikingly, in all his wartime letters to Freya, he never once mentions a legal issue or argument. This is not because she wouldn't understand. Freya von Moltke had a doctorate in law, a credential Helmuth himself lacked, as he was fond of pointing out when he introduced her to people. It would have been natural to at least mention in passing what his legal arguments were - if they mattered to him. Evidently, they didn't, at least not very much. ${ }^{195}$ Morality and religion were what mattered.

The defining feature of Moltke's conscience was his profound Christianity. Much of his time in prison was spent reading the Bible and praying. After his death sentence, he writes to Freya,

I wonder if I am a bit high, for I can't deny that my mood is positively elated. I only beg the Lord in Heaven that he will keep me in it, for it is surely easier for the flesh to die like that. How merciful the Lord has been to me! Even at the risk of sounding hysterical: I am so full of gratitude that there is hardly room for anything else. He guided me so firmly and clearly these 2 days. ${ }^{196}$

Most astonishing is his description of his trial, before the monstrous Nazi fanatic Roland Freisler, the President (i.e., presiding judge) of the People's Court. Far from hating or fearing Freisler, Moltke writes-without entire irony_ "Vivat Freisler!" because Freisler understands him and understands why he must kill him: "it is not plans or preparations but the spirit itself that is to be persecuted."197 He explains to Freya the day before his execution:

In one of his tirades Freisler said to me: "Only in one respect are we and Christianity alike: we demand the whole man." I don't know if the others sitting there took it all in, for it was kind of a dialogue - a spiritual one between F. and myself, ... in which we two got to know each other through and through. Of the whole gang Freisler was the only one who recognized me, and of the whole gang he is the only one who knows why he has to kill me... We talked, as it were, in a vacuum. He made not a single joke at my expense, as he had done with Delp and Eugen. No, this was grim earnest: "From whom do

195. As early as 1934, Moltke bitterly remarked that "the old jurisprudence I learned, based on an abstract concept of justice and humanity, is only of historical interest today." GRAF VON MOLTKE, supra note 49, at 79 (including a letter from Moltke to Karin Michaelis on Mar. 7, 1934).

196. LetTers to FreYA, supra note 47, at 406 (including a letter from Moltke to Freya on Jan. 10, 1945).

197. Id. at 405 . 
you take your orders? From the Beyond or from Adolf Hitler?" "Who commands your loyalty and your faith?" All rhetorical questions, of course. Anyhow, Freisler is the first National Socialist who has grasped who I am 198

His letter goes on:

Dear heart, my life is finished .... This doesn't alter the fact that I would gladly go on living and that I would gladly accompany you a bit further on this earth. But then I would need a new task from God. The task for which God made me is done. If he has another task for me we shall hear of it. Therefore by all means continue your efforts to save my life, if I survive this day. Perhaps there is another task. ${ }^{199}$

He ends the letter with a prayer for his loved ones, offered "by virtue of the treasure that spoke from me and filled this humble earthen vessel."200

Moltke's last letters are incomparably moving. Yet to ascribe all of Moltke's actions to his faith is, I think, too simple. The role of faith in his conscience is more complicated.

His parents were Christian Scientists, but he never adopted their religion. His biographers think that as late as 1935 Moltke had little or no religious commitment. ${ }^{201}$ That changed. In 1941 he wrote to Freya, "I became aware of a change that has taken place in me during the war, which I can only ascribe to a deeper insight into Christian principles." Christianity made him less pessimistic and better able to bear the suffering he saw. ${ }^{202}$ A few weeks later he wrote her again, deploring "the ignorance of the first foundations of all European civilization, namely that every human being is an independent thought of the Creator."203

Most revealing is a letter smuggled to his English friend Lionel Curtis, also written in 1941:

Perhaps you will remember that, in discussions before the war, I maintained that belief in God was not essential for coming to the results you arrive at. Today I know I was wrong completely wrong. You know that I have fought the Nazis from the first day, but the amount of risk and readiness for sacrifice which is asked from us now, and that which may be asked from us tomorrow require more than right ethical principles. ${ }^{204}$

198. Id. at 408-409 (including a letter from Moltke to Freya on Jan. 11, 1945). Of course, his report about a "spiritual dialogue" with Freisler may well have been his own projection. We will never know how Freisler saw it. Freisler was killed when the Allies bombed the People's Court, less than three weeks after he condemned Moltke.

199. Id. at 412 .

200. $I d$.

201. BALFOUR \& FRISBY, supra note 48 , at 71.

202. Letters to Freya, supra note 47, at 170 (including a letter from Moltke to Freya on Oct. 11, 1941).

203. Id. at 195 (including a letter from Moltke to Freya on Dec. 11, 1941).

204. Quoted in BALFOUR \& FrISBY, supra note 48, at 185. 
This paragraph deserves some thought, as does the remark to Freya about how his deeper insight into Christianity allowed him to go on. On the one hand, he is discovering his faith and its truths; on the other, he is reflective enough to know that his faith has become a psychological necessity if he is to continue his efforts. The substance of his ethical principles is apparently no different from his previous secular principles; grounding them in religion has become necessary because it gives him the courage to act.

It seems, then, that Moltke's moral convictions began independent of Christianity. Perhaps he sought them in philosophy. In 1940, he wrote to Freya, "The day is over. I thought I'd chew on Kant a bit and write to you at leisure. Instead I spent the whole day fighting like a lion for a French officer's life which the Reich Marshall wants to have at all costs." ${ }^{205}$ But by the time he wrote Curtis a year later, he knew that Kant was not enough to make him go on. He needed Christ.

On one interpretation, Christian principles drove Moltke to act; on another, his felt need to act drove him to his Christian principles. Both seem likely. The latter route to faith is actually not so far from Kant, who maintained that God's existence is unknowable and unprovable, but belief in God is a postulate required by practical reason (the moral faculty). ${ }^{206}$

In the same letter, Moltke speaks about a "spiritual awakening" among some Germans, "coupled as it is with the preparedness to be killed, if need be." He adds:

But today it is beginning to dawn on a not too numerous but active part of the population that they have been misled, not that they are in for a hard time, not that they might lose the war, but that what is done is sinful, and that they are personally responsible for every savage act that has been done, not of course in a moral way, but as Christians. ${ }^{207}$

The fate of postwar Europe, he adds, hinges on whether "the picture of man can be reestablished in the breasts of our fellow-citizens," and this picture seems to be the fundamental Christian principle to which he becomes increasingly committed.

\section{TAKING STOCK}

What are we to make of these two figures, both of them astonishing in quite different ways? How do we evaluate the moral choices they made with an eye toward answering the questions with which we began? In answering these questions, how may we use their moral biographies to test Arendt's thesis?

205. LetTers to Freya, supra note 47, at 107 (including a letter from Moltke to Freya on Aug. 21, 1940).

206. See Immanuel Kant, Critique of Practical Reason, Ak. 5:124-132.

207. BALFOUR \& FrISBY, supra note 48 , at 184-185. 
In obvious ways, it is absurd to compare Lösener with Moltke. George Kennan wrote of Moltke, "I consider him, in fact, to have been the greatest person, morally, and the largest and most enlightened in his concepts, that I met on either side of the battle lines in the Second World War." ${ }^{208}$ He adds:

I record all this because the image of this lonely, struggling man, one of the few genuine Protestant-Christian martyrs of our time, has remained for me over the intervening years a pillar of moral conscience and an unfailing source of political and intellectual inspiration. ${ }^{209}$

Nobody will say this about Bernhard Lösener. Even taking his memoirs at face value, he seems at best like a moral $\mathrm{B}+$.

Yet Lösener's is no less instructive a biography than Moltke's. Most people are not like Moltke, any more than most tennis players are like Serena Williams or most chess players like Magnus Carlsen. That makes Lösener a more realistic model, although not a more edifying one.

A hard-nosed consequentialist would note that Lösener probably saved more lives and spared more people from persecution than Moltke did. To some that makes his conduct more praiseworthy than Moltke's. Even on its narrow terms, though, the consequentialist case is not straightforward. Consider five complications:

First, there may be no real-world correlation between the number of Mischlinge Lösener succeeded in excluding from persecutory laws and the ultimate fate of those people. By the time he left his job in 1943, the authorities had declared Germany judenrein ("free of Jews"). ${ }^{210}$ An estimated 20,000 Jews survived-some because they were Mischlinge or among Lösener's "privileged" mixed marriages, but many because they went into hiding. ${ }^{211}$ Lösener's estimates based on race registries and census counts of how many people his maneuverings saved are therefore high: he was looking at numbers on paper, not numbers in reality, where Mischling status did not guarantee safety. Furthermore, even in cases where he got the numbers right, he may have overestimated the difference that he made personally. Thus, when Lösener reports that he talked Himmler into sparing 20,000 Jews in mixed marriages from deportation to death camps, he assumes that the decisive factor was his advocacy. Himmler may have had other reasons of which Lösener was unaware, and other lobbyists with other agendas may also have had his ear.

208. KFNNAN, MEMOIRS 1925-1950, supra note 139, at 121.

209. Id. at 122 .

210. German Jews During the Holocaust, Holocaust ENCYClopedia, U.S. Holocaust MeMORIAL MUSEUM, https://encyclopedia.ushmm.org/content/en/article/german-jews-during-the-holocaust [https://perma. cc/T8DJ-6D6Q] (last visited Apr. 9, 2021).

211. Id. Between 160,000 and 180,000 German Jews perished and hundreds of thousands more became refugees. Id. 
Second, had the war not ended-or had it ended in German victory-there is little doubt that the regime would have gone after the Mischlinge soon enough. Even if Lösener saved a lot of lives, was he in a position to predict this ex ante? He tells us that Himmler and Heydrich disregarded all the Ministry's legal recommendations, so why did he think his efforts would be meaningful on consequentialist terms, especially in the long run?

Third, Lösener offers the typical argument that if he quit, a Party zealot in his place would have been far more damaging. ${ }^{212}$ Perhaps so, but why does he assume that Stuckart would have replaced him with a Party zealot? Stuckart was (to a degree) on Lösener's side, and if he had any disappointment with Lösener it was that Lösener's Nuremberg Laws obsession stopped them from doing more good. ${ }^{213}$

Fourth, Lösener tells us about legal battles that he won, mostly in the early years of the Third Reich, and about his struggles to make sure the victories were not rolled back. No doubt these were grueling campaigns. On the other hand, they were intermittent campaigns, and he stayed on the job for ten years. What was he doing the rest of the time, when he wasn't fighting over legal definitions of Jews? He doesn't say, but it seems probable that being Judenreferent was not an innocent line of work. A true consequentialist assessment of his career would have to include the harm that he doesn't mention as well as the good that he does.

No such questions arise about Moltke: his job was to obtain compliance by the Army with international law, and that appears to be what he devoted all his professional energies to. "My basic theme is this: what is right and lawful is good for the people, what is international law is good for the conduct of the war. And that is how I'll formulate it." 214

That stance was not a given. Balfour and Frisby note that " $\mathrm{t}]$ he Nazi leaders, who had neither respect for nor understanding of law, expected it to be used as a tool to further their purposes and looked to their legal advisers to find pretexts justifying whatever they wished to do." ${ }^{215}$ Such was the approach by the legal division of the OKW under Moltke's adversary Dr. Wagner. Finding legal pretexts was, notoriously, the approach taken by some government lawyers during the U.S. war on terror. ${ }^{216}$ It was not what Moltke did. His daily work appears to be entirely admirable.

Fifth and finally, part of the harm that remaining on the job may have caused is the intangible harm discussed earlier - the intangible harm of normalizing a criminal regime by one's mere presence: complicity by consorting. This, of course, would be true of Moltke as well, a point to which I'll return.

212. Jewish Desk, supra note 43 , at 45.

213. Schleunes, supra note 5 , at 100.

214. LETTERS TO FREYA, supra note 47, at 132 (including a letter from Moltke to Freya on Apr. 29, 1941).

215. BALFOUR \& FRISBY, supra note 48; LETTERS to FREYA, supra note 47, at 3, 99.

216. See generally, David Luban, The Torture Lawyers of Washington, in DAvid Luban, TORTurE, POWER, AND LAW (2014). 
In short, if the question is what a consequentialist in Lösener's position should do-stay or quit?-it is not as obvious as he thinks that staying was the right choice. But let's grant that it was the right choice. The consequentialist answer "stay!" to the "stay or quit?" dilemma is in that case the right one. The bottom line is simple: by staying, he saved a great many people, maybe thousands. By leaving he could have done nothing.

Yet there is something unsatisfying, dissonant, about judging these biographies solely in consequentialist terms of how many expected lives they saved. Intuitively: character matters, motives matter, moral vision matters, self-honesty and self-deception matter, the day to day texture of life matters, complicity matters. As Lepora and Goodin argue—persuasively, to my way of thinking—acting based on the bottom line may be the right thing to do, but it nevertheless comes at moral cost. To borrow Bernard Williams's phrase, it leaves a moral remainder. ${ }^{217}$ How shall we think about the moral remainder?

\section{BADNess, Responsibility, Contribution, Shared Purpose}

Lepora and Goodin offer a useful four-factor schema for evaluating that moral remainder in cases of complicity. I will adopt it.

How morally blameworthy an act of complicity is is a function of four things: the moral badness of the principal wrongdoing; whether (and, insofar as it is scalar, by how much) the secondary agent crosses the threshold of moral responsibility for having contributed to it; how much of a contribution his act made (or might make) to the principal wrongdoing; and the extent to which the secondary agent shares the purposes of the principal wrongdoer. ${ }^{218}$

First is the "badness factor" of the principal wrongdoing. In Lösener's case the principal wrongdoing was the persecution of the German Jews, and in Moltke's it was the war crimes of the German military. Both are terrible-no comfort there. Second is their "responsibility factor," meaning how voluntary and knowledgeable their actions were. Neither man acted under compulsion, ignorance, or

217. LePORA \& GOOdIN, supra note 7, at 27-29; BERNARd WILliaMs, PROBLEMS OF THE SELf 179 (1976).

218. LEPORA \& GOODIN, supra note 7, at 97. These factors are mostly consistent with Kutz's analysis of individual moral accountability for participating in wrongful collective actions. Kutz, supra note 7, at 146 65. The principal difference is that Kutz focuses more on the binary threshold question "Is the individual participant culpable?" whereas Lepora and Goodin focus more on the question of degree: "How culpable is the individual participant?" Thus, Kutz endorses a "Complicity Principle" that holds the individual accountable for collective wrongdoings provided that the individual's participation in the joint enterprise was intentional, regardless of the consequential difference that individual makes. Id. at 116 . He does, however, acknowledge that differing circumstances may call for different responses. $I d$. at 165 . These differences include the fact that "some participants are unaware of the specific nature of the wrong or harm," and "some would prefer that aspects of the shared project go unrealized." Id. I believe that Lepora and Goodin's four factors, along with the additional factor of character that I discuss below, are helpful in fleshing out Kutz's more general point that differing circumstances call for different responses. 
illusion. ${ }^{219}$ Both stayed in their jobs knowingly and voluntarily. No comfort there either.

Next consider the "contribution factor," the causal role the men played in the principal wrongdoing. ${ }^{220}$ Here there is comfort. In Moltke's case, the direct causal role in evil is non-existent: all his professional energies were directed to preventing war crimes, not justifying or excusing them through legal means. Nor does the record disclose any indirect contribution through consorting with wrongdoers and normalizing the unforgivable in the eyes of his co-workers. On the contrary: Moltke fearlessly spoke up against wrongdoing even when he was a minority of one against twenty-five, and he was even able to persuade others to oppose criminal Führer Orders. He explicitly raised moral arguments to persuade or shame Bürkner into opposing the Commando Order. His minority influence was on the right side. Even ignoring his resistance activities outside his law job, Moltke made no causal contribution to wrongdoing. ${ }^{221}$

Lösener's case is more complicated. He did, after all, draft the Nuremberg Laws, the decrees, and the commentary. That comes close to making him a principal in legalized persecution, not a "mere" accomplice-but, even if we reserve principal status to those who executed the laws, and classify legislative drafters as accomplices, on its face there is no question that he played a direct and substantial causal role in evil.

Or did he? Another way of looking at causation is that a mitigator's causal contribution to the wrongdoing is negative rather than positive. Lösener's unique contributions to the Nuremberg Laws were the clauses he fought for that shrank the number of people who would be persecuted. It follows that Lösener was not a "but-for" cause of the evil. It is simply untrue that but for Lösener the evil would not have occurred, nor that but for Lösener it would have harmed fewer people. Just the contrary. The persecutory clauses would have been drafted anyway, and they would have swept in more people.

But if we also suppose that, as a legal technician, Lösener had a hand in drafting some or all the persecutory clauses as well, along with the implementing

219. Lösener does write that "As a civil servant, one could not leave the Party without exposing oneself and one's family to personal catastrophe." Jewish Desk, supra note 43, at 37. But nothing required him to remain at the Jewish Desk, or even in the Interior Ministry - and, for that matter, he could have resigned without facing persecution, although resignation would have left him jobless. A better man than Lösener might have paid this price. See, for example, the story of Paul Grüninger, a Swiss border official who paid that price, in Eyal Press, Beautiful Souls: The Courage and Conscience of Ordinary People in Extraordinary Times 11-46 (2013).

220. Lepora and Goodin's "contribution factor" is more fine-grained: in addition to the causal role of the actor, they include the proximity of the action to the principal wrongdoing, the reversibility of the contribution, whether the principal wrongdoing is or is not ongoing, the secondary actor's planning role, and how responsive the secondary actor is to the principal's plan. LEPORA \& GOODIN, supra note 7, at 107. For present purposes, I will not use all these elements.

221. With one possible exception: that his presence in the government may have helped normalize the regime in the eyes of outsiders who knew nothing about his activities other than that he was a respectable son of a famous family working in the Abwehr. I take up this point in the Epilogue. 
decrees, this exoneration is less clear. Wielding the pen and word-smithing the statutes is, straightforwardly, causation. If someone does something bad and defends himself by saying "if I didn't do it someone else would have" (or even "would have done worse") we may or may not exonerate him of guilt, but it would be insane to deny causation. Somebody did it, and it was him. The complication, then, is that Lösener made both positive and negative causal contributions to the evil of the Nuremberg Laws, and from a strictly causal point of view both are real and they don't cancel each other out.

If there is a difference between Lösener and the other drafters, it lies in their aims and intentions: he participated mostly to be in a position to mitigate. That brings us to the fourth factor, shared purpose. Surely it matters that Lösener's purpose was to mitigate, not to perpetrate. As he tells his story, his purpose was never to persecute Jews, even as he was drafting the Nuremberg Laws. Although then and later he had to engage in horrible compromises like the sterilization order, it was for a worthy purpose. Avishai Margalit distinguishes between bad compromises and rotten compromises. Compromising with radical evil is rotten and must not be done-but even Margalit believes that compromising with Nazis to save human beings from death and humiliation is bad, but not rotten. ${ }^{222}$

On the other hand, Lösener shared some purposes with the regime: he was a Party member by ideological conviction. And, by his own account, his proximate goal was not an egalitarian Germany, but rather a pacified Jim Crow Germany built on second-class (but livable) status for Jews. Lepora and Goodin rightly note that "shared purpose" is a matter of degree, and Lösener's was far from the lowest degree. ${ }^{223}$ It hardly needs adding that Moltke (who never joined the Nazi Party) shared no purposes whatever with the Nazis-indeed, he was further from them than anyone else in the Widerstand.

What about character? Lepora and Goodin are not inclined to include the actor's character in their formula of culpability. ${ }^{224}$ Yet writing this double moral biography, I find reflection on character inescapable. Let me offer a few brief thoughts, beginning with the virtues they shared.

First, it's striking that neither man underwent the gradual corruption of moral judgment that Arendt warns against. They stuck by their principles, and their time in the Hitler government never eroded their moral commitments. I've argued that Lösener was saddled with self-deception and false consciousness about several things. He had anti-Jewish prejudices and racialist views, and his claim that he never thought Hitler really meant his racist rants does not ring true. But Lösener insists that he always opposed persecution, and the record gives no reason to doubt him.

222. Avishai Margalit, On Compromise and Rotten Compromises 23 (2010).

223. LEPORA \& GOODIN, supra note 7, at 108.

224. Id. at 29 n. 24,104 n. 15 . 
Second, both were courageous. Moltke took far bigger risks than Lösener, but Lösener also followed a dangerous course that took guts. Third, both of them wrestled with the question of complicity. (Remember that Lösener repeatedly discussed with his friends about whether he should quit or stay.) Questions of conscience mattered to them; they thought about them. And both worked "off the books" to rescue individuals.

Importantly, their religion, which included a commitment to "basic humanity" (Lösener) and the Christian "picture of man" (Moltke), anchored their moral judgment - although, as I've argued, the interaction between faith and morality is not simple.

At this point, the similarities run out. Moltke was a resistance organizer. Lösener tells us that he was a member of the Goerdeler resistance circle since $1936,{ }^{225}$ but if so his role must have been peripheral; there is no mention of him in major histories of the Goerdeler circle. ${ }^{226}$ Moltke had a broad political and moral imagination, while Lösener was far narrower, and more narrowly legalistic. Lösener was "cramped up" fighting over points of persecution law; Moltke, in Kennan's estimation, was the largest and most enlightened in his conceptions of anyone Kennan met in the dark years.

\section{CONDITIONS For LESSER-EvILISM To SUCCEED}

To stay or to quit? One way to approach the question is to ask why an official in Lösener or Moltke's shoes should quit. I can think of four reasons, and none of them applies:

1. The official can't do any good by staying, so continued association is unmitigated participation in evil. This was evidently not true of Lösener and Moltke, who accomplished a great deal by staying that they could not if they left their job. Perhaps they didn't accomplish as much good as they thought they did, and certainly not as much as they hoped for. But they saved human lives and dignity, on a significant scale.

2. Quitting in protest would do some good, perhaps inspiring others to do so in a snowball effect. I see nothing in the historical record to suggest that Lösener's or Moltke's resignation would have had any such effect.

3. If you don't quit, your judgment will be corrupted: "those who choose the lesser evil forget very quickly that they chose evil." ${ }^{227}$ It may happen-but in these cases it did not.

225. Jewish Desk, supra note 43, at 39.

226. That includes MOMmsen, Alternatives to Hitler, supra note 132; Peter Hoffman, Carl Goerdeler AND the Jewish Question, 1933-1942 (2013); INes Reich, CARL Friedrich Goerdeler: Ein Oberbürgermeister gegen den NS-StaAt (1997); Politische Schriften und Briefe Carl Friedrich Goerdelers (Sabine Gillmann \& Hans Mommsen, eds., 2003).

227. ARENDT, Personal Responsibility, supra note 2, at 36 . 
4. Staying on the job is complicity by consorting, and it contributes to the moral breakdown of those around you. Obedience is support, and the appearance of obedience is, in politics, reality. Perhaps this is true, and I think it is the argument that matters the most to Arendt. But in our two cases, the intangible contribution to moral breakdown seems far outweighed by the concrete good these two did. More about this in the epilogue below.

So I think Arendt got it quite wrong: it's at least possible to stay on in the job without undergoing or contributing to moral collapse. But it is worth asking how that happens. Here, several conditions seem essential.

To take the most obvious: the only thing that justifies staying in the job is continually trying to accomplish some good or at least prevent some concrete evil. To stay on the job but become complacent is to violate Moltke's "inescapable duty of all the righteous to keep crime within bounds." Non-resisters need not apply for exoneration.

This may seem so obvious that it's trivial, but the moral counterweight is that to resist the government's policy will be disloyal. That is not trivial. Arendt, commenting on the German resistance, is probably right that "the endless conflicts and crises of conscience under which they labored hinged almost exclusively on the problem of high treason and the violation of their loyalty oath to Hitler."228 Even when opposition does not rise anywhere near the level of high treason, personal loyalty to colleagues and a sense of professional duty will weigh heavily against resistance.

So will the completely understandable urge to hold your fire until something more important comes along — which may turn out to be holding your fire forever. James C. Thomson-among the first U.S. government officials to resign in protest of the Vietnam War-called this "the 'effectiveness' trap":

The most important asset that a man brings to bureaucratic life is his "effectiveness," a mysterious combination of training, style, and connections.... To preserve your effectiveness, you must decide where and when to fight the mainstream of policy .... The inclination to remain silent or to acquiesce in the presence of the great men- to live to fight another day, to give on this issue so that you can be "effective" on later issues - is overwhelming. ${ }^{229}$

It is "the trap that keeps men from speaking out, as clearly or as often as they might, within the government. And it is the trap that keeps men from resigning in protest and airing their dissent outside the government." ${ }^{230}$ The resister will need great confidence in her moral judgment to go forward. And if she does not go

228. ARENDT, EICHMANN IN JERUSALEM, supra note 2, at 98.

229. James C. Thomson, How Could Vietnam Happen? An Autopsy, THE ATLANTIC (Apr. 1968), https:// www.theatlantic.com/magazine/archive/1968/04/how-could-vietnam-happen-an-autopsy/306462/ [https:// perma.cc/6ZQ3-J6RZ].

230. $I d$. 
forward, if she joins the "complacent state," she made the wrong choice by staying. That, I take it, is Arendt's point.

It seems at least plausible that a collateral benefit of active resistance is keeping one's moral judgment firm. Speaking out requires the resister to rehearse her arguments and marshal her will; it commits her to the high road and makes later backtracking more embarrassing. A model in which sound moral judgment leads to sound action is too simple: it is a two-way connection, a virtuous circle. I suspect that if Lösener and Moltke both kept their commitment firm, it was by continuing to act.

But - a third lesson of these cases - resistance will be futile without Spielraum, and concretely Spielraum requires allies or at least silent sympathizers. I've speculated that actors fighting the good fight within an organization can to a degree create their own Spielraum. Sometimes they do it by winning over others to the cause or at least weakening their resistance; sometimes simply by creating friction in the machine. But without allies, or at least partial allies, there will not be enough Spielraum to resist. In that case, the calculus of staying or quitting reverses: staying means participating in evil that you cannot mitigate.

In that case, Arendt is right: obedience is support. It's time to exit.

\section{AN EPILOGUE}

Friederich Percyval Reck-Malleczewen-"Fritz Reck" to his friends-was an aristocratic conservative in Munich who bitterly watched Hitler's rise from the earliest days. Reck kept a journal, written in matchless invective, which was published two years after his death under the title Diary of a Man in Despair. From the beginning, Hitler horrified him ("a deeply miscarried human being sprung out of some Strindbergian excremental Hell") and he despised the masses who brought Hitler to power ("a horde of vicious apes"). ${ }^{231}$ Reck hid his journal, but apparently not his opinions. The Gestapo arrested him in 1944 for subversion and he died in Dachau in February 1945 at age sixty-one.

Reck was a quintessential aristocratic anti-Nazi, and one might suppose he would applaud the resisters. He did not. Here is Reck's journal entry from the day after the failed July 20th assassination:

Ah, now, really, gentlemen, this is a little late. You made this monster, and as long as things were going well you gave him whatever he wanted. You turned Germany over to this archcriminal, you swore allegiance to him by every incredible oath he chose to put before you-you, officers of the Crown, all of you.... And now you are betraying him, as yesterday you betrayed the Republic, and as the day before yesterday you betrayed the Monarchy. Oh, I don't doubt that if this coup had succeeded, we, and what remains of the

231. Friedrich Percyval Reck-Malleczewen, Diary of a Man in Despair [Tagebuch eines VERZWEIFELTEN], (Paul Rubens trans., 1970). The quotations are from the long and astonishing entry for Aug. $11,1936 . I d$. at $22,26-27$. 
material substance of this country, would have been saved. I am sorry, the whole of this nation is sorry, that you failed... . I am a conservative... . I derive from monarchical patterns of thinking.... And yet-not despite this fact, but because of it - I hate you. Coquettes who flirt with every passing political adventurer! $!^{232}$

Moltke was neither bomb plotter nor military officer, but Reck includes him in his diatribe:

Ah, this unworthy nephew of great Moltke and all his caste. . . For years, these men were the cover for every treasonable act, every orgy of rape and murder .... And now that the firm is going bankrupt, they are betraying it to provide themselves with a political alibi. ... ${ }^{233}$

It goes without saying that including Moltke among the "coquettes" has nothing to do with reality. Reck portrays the resisters as opportunists who backed Hitler for selfish reasons, then betrayed him for equally selfish reasons. Possibly that was true of some, but not of Moltke. It is puzzling why Reck lumps Moltke together with the bomb plotters, or how he even knew Moltke was part of the resistance. Perhaps he heard rumors through the grapevine; but if so he surely knew that Moltke was already arrested and imprisoned six months before July 20 . Or perhaps Reck knew only that the Abwehr had fallen under suspicion and been dissolved and drew his own conclusions about the men associated with it. ${ }^{234}$ Reck almost certainly knew nothing of Moltke's legal work to forestall atrocities, which is one reason his accusation is unjust.

For our purposes, though, Reck's misunderstanding suggests a genuine danger of staying on the job that I mentioned earlier. Reck accuses the resisters of providing cover for Hitler's crimes, for example by swearing the "incredible" oaths of loyalty to the Führer (not to the country) required of German military officers. ${ }^{235}$ In other words, he accuses them of normalizing the regime in the eyes of a nation that knew nothing of their secret opposition. If Fritz Reck-who closely followed the news and hated the Nazis - could so thoroughly misread Moltke and many other resisters, then why wouldn't less informed and more ambivalent Germans mistake their seeming obedience for support, and draw assurance that the regime was on track from the apparent support of established names? This is what Lepora and Goodin call complicity by consorting, and the danger of consorting with evil is that it causes other to mistake it for active support. ${ }^{236}$ So Arendt would likely argue.

232. Id. at $195-96$ (entry of July 21,1944 ).

233. Id. at 197.

234. However, Admiral Canaris was not arrested until two days after Reck's diary entry.

235. As a civilian, Moltke did not swear that oath.

236. In Lepora and Goodin's typology of complicity, support can take several forms: outright collaboration, connivance (tacit approval, "winking and nodding"), or condoning (ignoring or excusing wrongdoing). LEPORA \& GoODIN, supra note 7, at 42-50. 
Arendt was not an admirer of the German Widerstand, proclaiming "the political bankruptcy of the resistance movement as a whole since 1933." ${ }^{237}$ Her discussion of the resistance groups is quite well informed, but it is also harsh and brittle. She had little patience with moral compromise and less with wishful thinking. Perhaps, then, it should come as no surprise that Arendt quotes some of the passage reproduced above from Fritz Reck's journal entry and comments, "There is indeed every reason to agree with the bitter judgment on these men. ${ }^{, 238}$ It should be clear by now that there is every reason not to agree with Reck's bitter judgment.

When I began this study, I was inclined toward Arendt's overall argument, which seemed like a clearheaded and realistic diagnosis of two indisputable observations: that the early years of the Third Reich saw a breakdown in the personal judgment of millions of people, and that the late years saw a total moral collapse. Her argument in "Personal Responsibility Under Dictatorship" seems like a plausible response: get out and go home, for if everyone did so the regime would collapse. The trouble is that very few will go home. For that reason, Arendt's answer is too easy.

The moral biographies of Lösener and Moltke, the resistant Nazi and the antiNazi, both working in the government, suggest why. Sometimes quitting is the right thing to do; but when there is Spielraum, and a genuine prospect of mitigating evil, staying at the desk can be the righteous path. But only for those who actually resist. This is a lesson that matters today as well as yesterday, and in other regimes than dictatorships.

237. ARendt, Eichmann In Jerusalem, supra note 2, at 99.

238. Id. at 102 . 